This is the final peer-reviewed accepted manuscript of

Di Vincenzo, G.; Grande, A.; Prosser, G.; CAVAZZA, WILLIAM; DeCelles, P. G.: 40Ar-39Ar laser dating of ductile shear zones from central Corsica (France): evidence of Alpine (middle to late Eocene) syn-burial shearing in Variscan granitoids. LITHOS 262. ISSN 0024-4937

DOI: $10.1016 / j . l i t h o s .2016 .07 .022$

The final published version is available online at:

http://dx.doi.org/10.1016/.j.lithos.2016.07.022

Rights / License: The terms and conditions for the reuse of this version of the manuscript are specified in the publishing policy. For all terms of use and more information see the publisher's website. 


\title{
Paleotectonics of a complex Miocene half graben formed above a detachment fault: The Diligencia basin, Orocopia Mountains, southern California
}

\author{
Raymond V. Ingersoll',*, Mark J. Pratt', Paul M. Davis', Luca Caracciolo², Paul P. Day'1, Paul O. Hayne ${ }^{1,3}$, Daniel A. Petrizzo', David A. Gingrich', \\ William Cavazza ${ }^{4}$, Salvatore Critelli², David S. Diamond ${ }^{5}$, Kevin T. Coffey ${ }^{1}$, Dallon M. Stang ${ }^{1,6}$, Johanna F. Hoyt ${ }^{1,6}$, Robin C. Reith ${ }^{1,7}$, and Eric D. \\ Hendrix ${ }^{1,8}$ \\ 'DEPARTMENT OF EARTH, PLANETARY AND SPACE SCIENCES, UNIVERSITY OF CALIFORNIA, LOS ANGELES, CALIFORNIA 90095-1567, USA \\ 2DIPARTIMENTO DI SCIENZE DELLA TERRA, UNIVERSITÀ DELLA CALABRIA, VIA P. BUCCI, CUBO 15 B, 87036, RENDE (COSENZA), ITALY \\ 3JET PROPULSION LABORATORY, CALIFORNIA INSTITUTE OF TECHNOLOGY, MS 183-301, 4800 OAK GROVE DRIVE, PASADENA, CALIFORNIA 91109, USA \\ ${ }^{4}$ DIPARTIMENTO DI SCIENZE BIOLOGICHE, GEOLOGICHE E AMBIENTALI, UNIVERSITÀ DI BOLOGNA, PIAZZA DI PORTA SAN DONATO 1, 40126 BOLOGNA, ITALY \\ 5 LAWRENCE BERKELEY NATIONAL LABORATORY, ENVIRONMENTAL RESTORATION PROGRAM, 14R0108, ONE CYCLOTRON ROAD, BERKELEY, CALIFORNIA 94720-8233, USA \\ ${ }^{6}$ AERA ENERGY LLC, 10000 MING AVE., BAKERSFIELD, CALIFORNIA 93311, USA \\ 'OCCIDENTAL OIL AND GAS CORPORATION, 111 WEST OCEAN BLVD. SUITE 800, LONG BEACH, CALIFORNIA 90801, USA \\ ${ }^{8}$ EARTH CONSULTANTS INTERNATIONAL INC., 1642 EAST FOURTH STREET, SANTA ANA, CALIFORNIA 92701, USA
}

\section{ABSTRACT}

The Diligencia basin in the Orocopia Mountains of southeastern California has been one of the primary areas used to test the hypothesis of more than $300 \mathrm{~km}$ of dextral slip along the combined San Andreas/San Gabriel fault system. The Orocopia Mountains have also been the focus of research on deposition, deformation, metamorphism, uplift and exposure of the Orocopia Schist, which resulted from flat-slab subduction during the latest Cretaceous/Paleogene Laramide orogeny.

The uppermost Oligocene/Lower Miocene Diligencia Formation consists of more than $1500 \mathrm{~m}$ of nonmarine strata, including basalt flows and intrusions dated at 24-21 Ma. The base of the Diligencia Formation sits nonconformably on Proterozoic augen gneiss and related units along the southern basin boundary, where low-gradient alluvial fans extended into playa-lacustrine environments to the northeast. The northern basal conglomerate of the Diligencia Formation, which was derived from granitic rocks in the Hayfield Mountains to the north, sits unconformably on the Eocene Maniobra Formation. The northern basal conglomerate is overlain by more than $300 \mathrm{~m}$ of mostly red sandstone, conglomerate, mudrock and tuff. The basal conglomerate thins and fines westward; paleocurrent measurements suggest deposition on alluvial fans derived from the northeast, an interpretation consistent with a NW-SE-trending normal fault (present orientation) as the controlling structure of the half graben formed during early Diligencia deposition. This fault is hereby named the Diligencia fault, and is interpreted as a SW-dipping normal fault, antithetic to the Orocopia Mountains detachment and related faults. Deposition of the upper Diligencia Formation was influenced by a NE-dipping normal fault, synthetic with, and closer to, the exposed detachment faults. The Diligencia Formation is nonconformable on Mesozoic granitoids in the northwest part of the basin.

Palinspastic restoration of the Orocopia Mountain area includes the following phases, each of which corresponds with microplate-capture events along the southern California continental margin: (1) Reversal of $240 \mathrm{~km}$ of dextral slip on the San Andreas fault (including the Punchbowl and other fault strands) in order to align the San Francisquito-Fenner-Orocopia Mountains detachment-fault system at 6 Ma. (2) Reversal of N-S shortening and $90^{\circ}$ of clockwise rotation of the Diligencia basin and Orocopia Mountains, and $40 \mathrm{~km}$ of dextral slip on the San Gabriel fault between 12 and $6 \mathrm{Ma}$. (3) Reversal of $40^{\circ}$ of clockwise rotation of the San Gabriel block (including Soledad basin and Sierra Pelona) and $30 \mathrm{~km}$ of dextral slip on the Canton fault between 18 and $12 \mathrm{Ma}$.

These palinspastic restorations result in a coherent set of SW-NE-trending normal faults, basins (including Diligenica basin) and antiformal structures consistent with NW-SE-directed crustal extension from 24 to $18 \mathrm{Ma}$, likely resulting from the unstable configuration of the Mendocino triple junction.

\section{INTRODUCTION}

The Diligencia basin is located in the Orocopia Mountains of southeastern California, north of the Salton Sea (Fig. 1). The Orocopia Mountains are bounded to the west by the San Andreas fault, on the north by the Chiriaco fault,

*ringer@ess.ucla.edu on the south by the Salton Wash fault and on the east by the Sheep Hole fault (Figs. 1 and 2). Beginning with Crowell's (1960, 1962, 1975a) suggestion of more than $300 \mathrm{~km}$ of dextral slip along the combined San Andreas/San Gabriel fault system, the Orocopia Mountains have been one of the primary areas used to test this hypothesis. The Orocopia Mountains have also been the focus of research on deposition, defor- mation, metamorphism, uplift and exposure of the Orocopia Schist, which resulted from flatslab subduction during the latest Cretaceous/ Paleogene Laramide orogeny (e.g., Jacobson et al., 2000, 2002, 2007, 2011; Grove et al., 2003).

The present contribution emphasizes the origin and subsequent deformation of the uppermost Oligocene/Lower Miocene Diligencia Formation (Crowell, 1975b; Spittler and Arthur, 


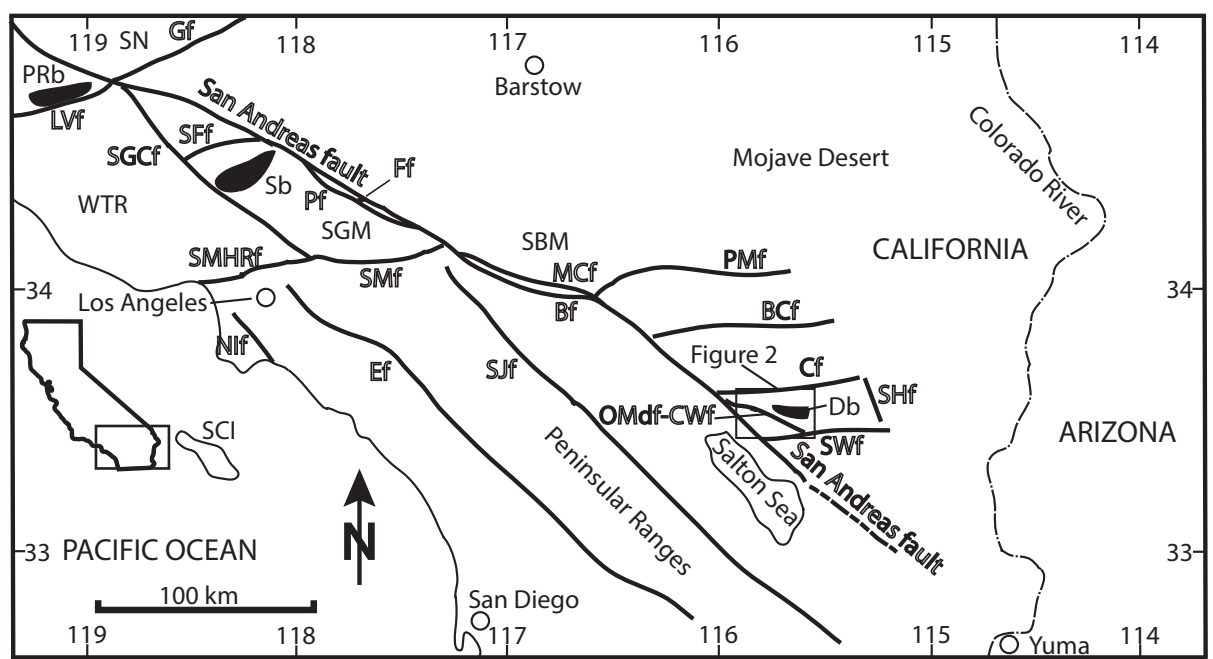

Figure 1. Location map of Diligencia ( $\mathrm{Db}$ ) and related basins of southern California ( $\mathrm{Sb}-$ Soledad basin; PRb-Plush Ranch basin). Abbreviations for physiographic features include: SBM-San Bernardino Mountains; SCI-Santa Catalina Island; SGM-San Gabriel Mountains; SN-Sierra Nevada; WTR-Western Transverse Ranges. Faults and their abbreviations are shown in bold: Bf-Banning fault; BCf-Blue Cut fault; $\mathrm{Cf}-$ Chiriaco fault; OMdf-CWf-Orocopia Mountains detachment fault-Clemens Well fault; Ef-Elsinore fault; Ff-Fenner fault; LVf-Lockwood Valley fault; MCfMill Creek-Mission Creek faults; NIf-Newport Inglewood fault; Pf-Punchbowl fault; PMf-Pinto Mountain fault; SFf-San Francisquito fault; SGCf-San Gabriel-Canton faults; SHf-Sheep Hole fault; SJf-San Jacinto fault; SMf-Sierra Madre fault; SMHRf-Santa Monica-Hollywood-Raymond faults; SWf-Salton Wash fault. Rectangle shows location of Figure 2. After Law et al. (2001).

1982; Squires and Advocate, 1982; Law et al., 2001), for the combined purposes of better understanding the details of sedimentation, stratigraphy, basin development, structural deformation and tectonic setting. A detailed geologic map of the area (Fig. 3 and Plate $1^{1}$ ) compiled from previous mapping and our new mapping provides geometric constraints on our interpretations. This information is used to refine models for plate-tectonic controls on basin development, transrotational deformation, basin inversion and fault offsets along the San Andreas fault system. Ultimately, these results and models will refine and improve our understanding of paleotectonic and paleogeographic development of southern California and neighboring areas.

A detailed summary of all previous work in the study area may be found in the Data Repository [see footnote 1]. All references to Figure 3 also refer to Plate 1 in the Data Repository.

\section{GEOLOGIC SETTING}

The Orocopia Mountains and the Hayfield Mountains consist of Proterozoic gneiss and plu-

'GSA Data Repository Item 2014166, Plate 1, Tables $1-3$, and a summary of previous work, is available at www.geosociety.org/pubs/ft2014.htm, or on request from editing@geosociety.org, Documents Secretary, GSA, P.O. Box 9140, Boulder, C0 80301-9140, USA. tonic rocks (Pgn and PMc), Mesozoic plutonic rocks (PMc and $\mathrm{Mg}$ ), Upper Cretaceous-Paleogene Orocopia Schist (KTos), marine Eocene Maniobra Formation (Tm), nonmarine OligoMiocene Diligencia Formation (Td) and diverse nonmarine Pliocene-Quaternary sedimentary units (TQa) (Crowell, 1975b; Spittler and Arthur, 1982; Law et al., 2001; Jacobson et al., 2007) (Figs. 2 and 3). The Orocopia Schist is exposed along the southwest side of the Diligencia basin, and is structurally overlain by Proterozoic and Mesozoic crystalline rocks; Mesozoic granitoids are exposed on the northeastern side of the basin and as isolated hills surrounded by Cenozoic sedimentary units (Fig. 3). The Maniobra Formation is nonconformable on the Mesozoic granitoids, as well as in fault contact; the Diligencia Formation is nonconformable on Proterozoic gneiss on the south and Mesozoic granitoids in the northwest, in angular unconformity on the Maniobra Formation on the north, and in fault contact with Proterozoic and Mesozoic crystal-

Syndepositional steep faults cut the Maniobra Formation and granitoid basement in the northern part of the study area; locally, some of these faults are overlapped by younger parts of the Maniobra Formation. Deposition of the Maniobra Formation likely occurred in a faultcontrolled submarine canyon (Advocate et al., 1988). The Maniobra and Diligencia basins line rocks in several locations (Fig. 3). have been shortened in a NNE-SSW direction (present orientation), as expressed by development of the basin synclinorium, as well as NNW-trending dextral faults and ENE-trending sinistral faults (Law et al., 2001) (Fig. 3). Undeformed flat-lying or gently dipping PlioceneQuaternary fanglomerate, older alluvium and modern alluvium overlie all older units.

\section{CRYSTALLINE ROCKS}

\section{Lower Plate}

The structurally lowest rocks of the Orocopia Mountains area constitute the Orocopia Schist (KTos) (Miller, 1944) (Figs. 2 and 3), part of the regionally extensive Pelona-Orocopia-Rand (POR) Schist terrane (Jacobson et al., 2011, and references therein). The POR Schist likely formed part of a subduction complex, resulting from low-angle subduction during the latest Cretaceous-Paleogene Laramide orogeny (Dickinson and Snyder, 1978; Livaccari et al., 1981; Bird, 1984, 1988; Jacobson et al., 1988, 1996, 2002, 2007, 2011; Ingersoll, 1997; Grove et al., 2003; Saleeby, 2003).

The Orocopia Schist primarily consists of quartzofeldspathic (arkosic) metasandstone, with minor amounts of metabasalt, metachert, marble, serpentinite and talc-actinolite rock (Jacobson et al., 2007). Peak metamorphism of the POR Schist locally reached epidote-blueschist and upper-amphibolite facies, although most of the exposed schist is greenschist or albite-epidote amphibolite. Inverted metamorphic zonation and retrograde metamorphism are common; all of these characteristics are consistent with deposition, deformation and metamorphism as part of a subduction complex (Jacobson et al., 2011, and references therein).

The faults at the tops of exposed POR Schist were originally interpreted as thrusts (e.g., Vincent thrust and Orocopia thrust; Ehlig, 1958, 1968, 1981), but the recognition of cataclasis, hydrothermal alteration and retrograde mylonitization prompted Jacobson et al. $(1988,1996)$ and Jacobson and Dawson (1995) to interpret the Orocopia fault as largely an extensional fault, with top-tothe-NE-and-east sense of shear (Jacobson et al., 2007). Robinson and Frost (1996) developed a model for extensional uplift of the Orocopia Schist along the Orocopia Mountains detachment fault and the Diligencia detachment fault; this model was modified by Ebert (2004) and Jacobson et al. (2007), and is accepted herein as the most useful model for overall controls on development of the Diligencia basin.

Based on U-Pb ages of detrital zircon from the Orocopia Schist, the protolith was deposited no older than $70 \mathrm{Ma}$ (Grove et al., 2003; Jacob- 


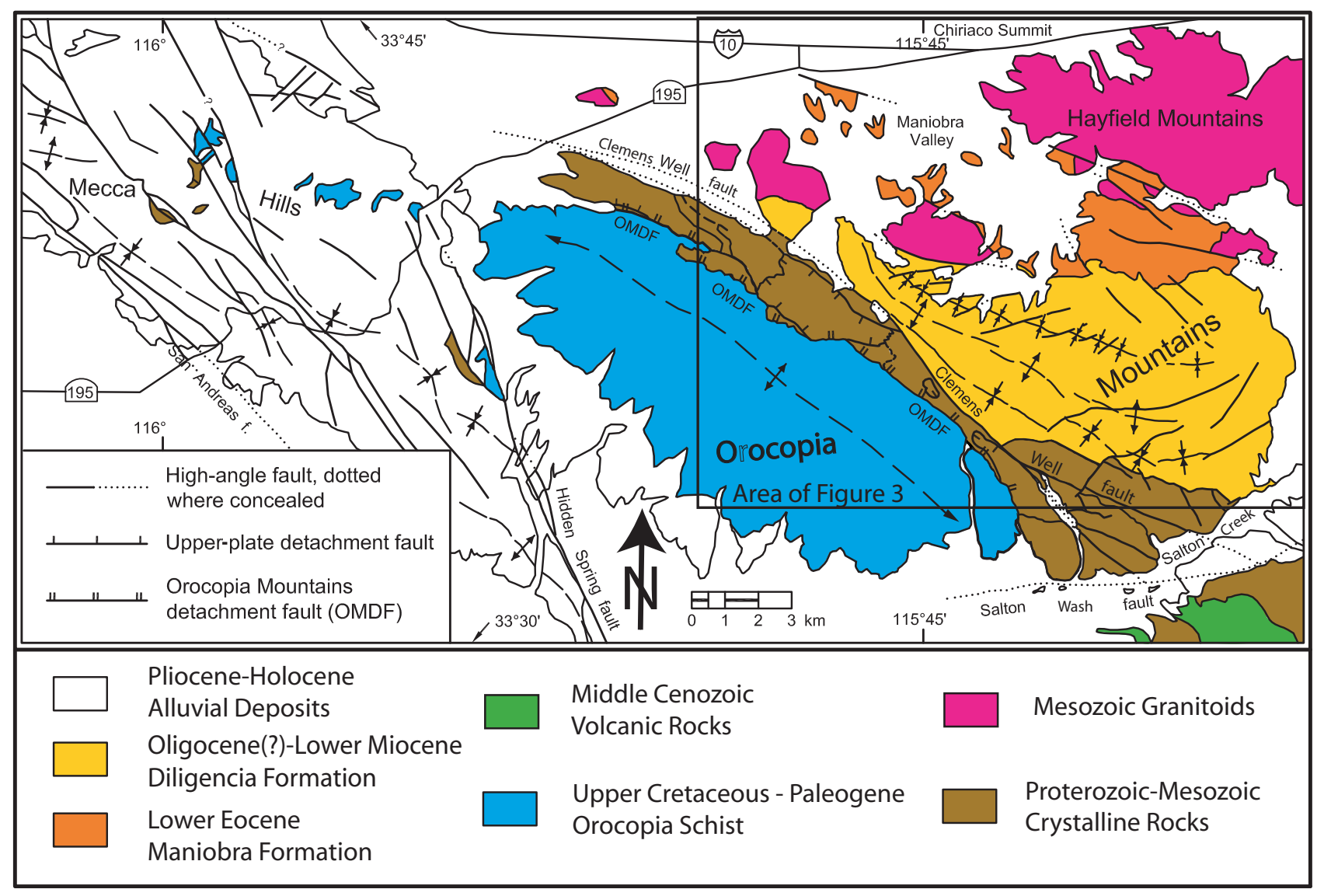

Figure 2. Geologic map of Orocopia Mountains region (after Crowell, 1975b; Jacobson et al., 2007). Maniobra Formation is nonconformable on Mesozoic granitoids; locally they are in fault contact. Diligencia Formation is in angular unconformity on Maniobra Formation to the north, is nonconformable on Proterozoic-Mesozoic crystalline rocks to the south, and nonconformable on Mesozoic granitoids to the northwest. The Clemens Well fault locally forms the boundary of the Diligencia Formation to the southwest. Figure 3 covers most of the eastern half of this map. After Caracciolo et al. (2013).

son et al., 2007, 2011). The average elapsed time from magmatic crystallization to erosion to deposition to underthrusting and metamorphism was $13 \pm 10$ m.y. for the POR Schists (Grove et al., 2003).

\section{Upper Plate}

Ehlig (1958, 1981), Crowell (1960), Crowell and Walker (1962), Jacobson (1980) and Ebert (2004) described the crystalline rocks structurally above the Orocopia Mountains and Diligencia detachment faults (Figs. 2 and 3), as follows. The oldest unit in the upper plate is Paleoproterozoic augen gneiss dated by $\mathrm{U}-\mathrm{Pb}$ methods on zircon at $1670 \pm 15$ Ma by Silver (1971); the augen gneiss is exposed only northeast of the Clemens Well fault, where it nonconformably underlies the Diligencia Formation. Southwest of the Clemens Well fault, the oldest unit consists of blue/purple-quartz gneiss (Ebert, 2004) (Augustine gneiss of Powell, 1981), which Silver (1971) dated at $1425 \mathrm{Ma}$; the Augus- tine gneiss is intruded by the $1220 \mathrm{Ma}$ (Silver et al., 1963; Silver, 1971) anorthosite-gabbrosyenite complex. Barth et al. (2001) reevaluated Mesoproterozoic metamorphism and plutonism of the Mendenhall gneiss (the probable offset equivalent of the Augustine gneiss across the San Andreas fault), and concluded that ages of $\sim 1400$ Ma resulted from averaging of 1700 Ma zircon cores with 1200 Ma zircon rims, resulting from high-temperature metamorphism during emplacement of the anorthosite-gabbrosyenite complex.

Leucogranite that intrudes the Augustine gneiss, and to a lesser extent, the anorthositegabbro-syenite complex, has average youngest $\mathrm{U} / \mathrm{Pb}$ ages of $76 \mathrm{Ma}$ (Ebert, 2004; Jacobson et al., 2007). Small granitic intrusions in the augen gneiss have not been dated, but they resemble the leucogranite. Armstrong and Suppe (1973) determined an age of $75 \mathrm{Ma}(\mathrm{K} / \mathrm{Ar})$ for the informally named Hayfield granite on the north side of the Diligencia basin (Figs. 2 and 3); this age may represent regional cooling, rather than plutonic crystallization (Jacobson et al., 2007). Joseph et al. (1982) determined a $\mathrm{Rb} / \mathrm{Sr}$ age of 83 Ma for a "polka dot granite dike" on the north side of the Diligencia basin. Late Cretaceous granite, granodiorite and quartz monzonite (informally designated the Hayfield granite, herein) dominate crystalline rocks of the north side of the basin; small pods of migmatite and gneiss also occur (Spittler and Arthur, 1982). Boundaries between Proterozoic rocks along the south and west sides of the Diligencia basin and Mesozoic granitoids along the north side and within the northwestern part of the study area (Fig. 3) are covered, and can only be inferred (Spittler and Arthur, 1982).

\section{EOCENE MANIOBRA FORMATION}

Dibblee (1954, p. 24) was the first to note the presence of Eocene sandstone with marine fossils in conglomerate clasts within the Pliocene Mecca Formation in the Mecca Hills west of the Orocopia Mountains. Crowell and Susuki 


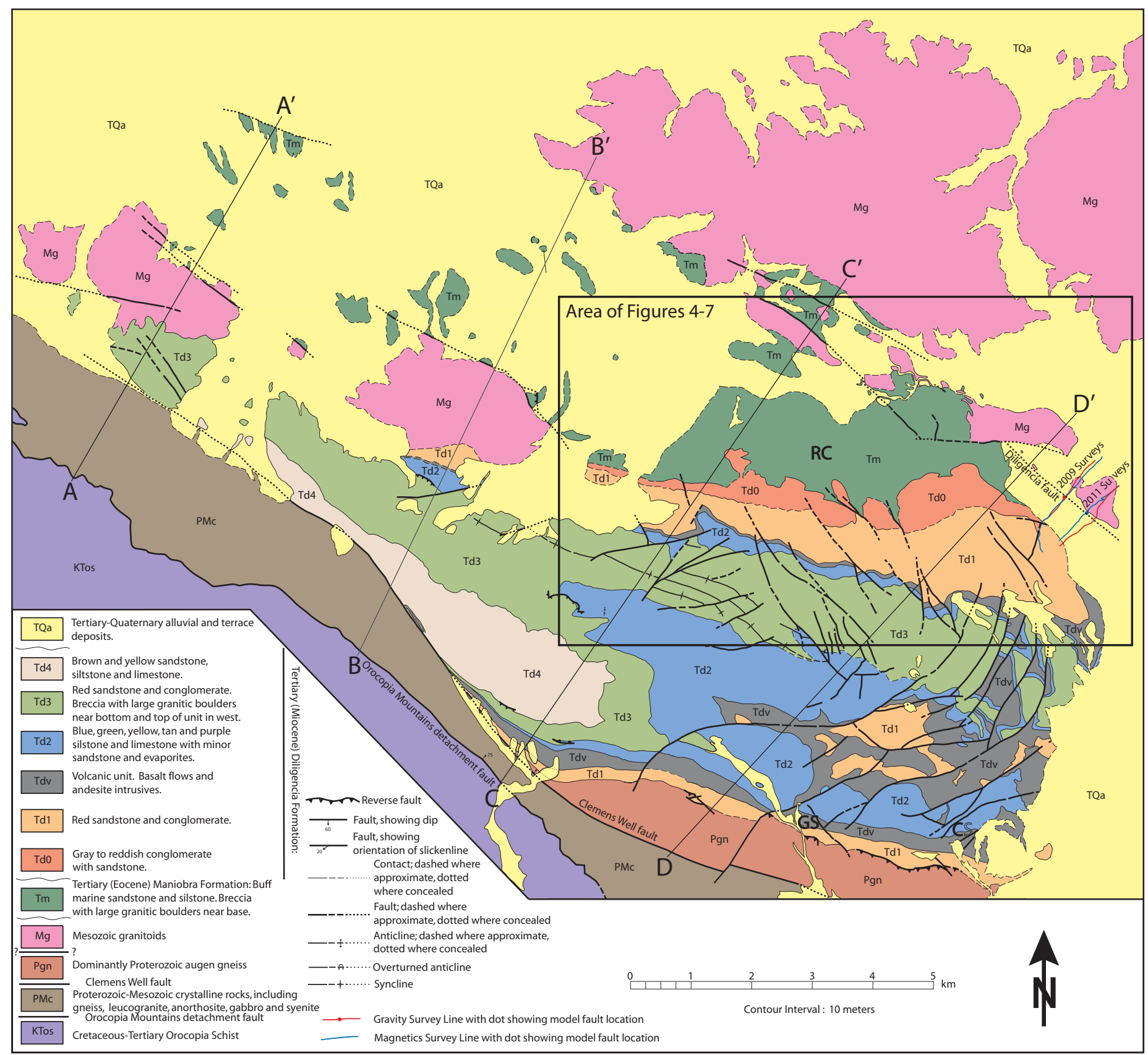

Figure 3. Geologic map of Diligencia basin and surroundings (compiled from Williams, 1956; Gillies, 1958; Crowell and Susuki, 1959; Arthur, 1974; Spittler, 1974; Crowell, 1975b, unpublished; Spittler and Arthur, 1982; Squires and Advocate, 1982; Advocate et al., 1988; Davisson, 1993; Law et al., 2001; Ebert, 2004; Jacobson et al., 2007). Many areas were remapped during the present study. CS-Canyon Spring. GS-Gucci Spring. RC-Red Canyon. Cross sections shown in Figure 11. Geophysical surveys shown in Figures 13-15. Detailed digital version of this figure is Plate 1 in Data Repository (see footnote 1).

(1959) incorporated the theses of Williams (1956), Gillies (1958) and Kirkpatrick (1958) into their characterization and definition of the Lower to Middle Eocene Maniobra Formation, whose type area is the Maniobra Valley (Figs. 2 and 3). Squires and Advocate (1986) reevaluated all paleontologic data and worldwide correlations to conclude that the Maniobra Formation was entirely Lower Eocene.
The Maniobra Formation consists of up to $1500 \mathrm{~m}$ of mudrock, sandstone and conglomerate, with local sandy limestone and conglomerate (Crowell and Susuki, 1959; Advocate et al., 1988). The base of the Maniobra Formation includes nonmarine deposits derived directly from the nonconformably underlying Cretaceous Hayfield granite (Williams, 1956; Crowell and Susuki, 1959); in places, there is a gradual upward transition from fresh granite to weathered granite to arkosic grus to reworked arkose, with local development of paleosols (Advocate et al., 1988). Well rounded granitic boulders occur in several locations within the basal beds, as well as higher in the section (Williams, 1956; Advocate et al., 1988). Diverse types of conglomerate, breccia, sandstone, mudrock and limestone constitute the remain- 
der of the Maniobra Formation, including abundant gravity-flow deposits, convoluted beds and slump features (Williams, 1956; Gillies, 1958; Kirkpatrick, 1958; Crowell and Susuki, 1959; Advocate et al., 1988).

The thin nonmarine basal Maniobra Formation is overlain directly by marine deposits, suggesting rapid subsidence following initiation of sedimentation (Williams, 1956; Advocate et al., 1988). The presence of granitic boulders up to $10 \mathrm{~m}$ in diameter at various locations along the margins of the exposures suggests rugged topography and fault-controlled deposition into marine environments (Kirkpatrick, 1958; Crowell and Susuki, 1959; Advocate, 1983; Advocate et al., 1988). Fossil assemblages and sedimentary structures suggest deposition below wave base in warm marine water for most of the formation (Kirkpatrick, 1958; Crowell and Susuki, 1959; Johnston, 1961). Graded beds, slump deposits and the presence of boulders in muddy deposits suggest deposition by gravity-flow processes (Kirkpatrick, 1958; Crowell and Susuki, 1959; Advocate et al., 1988).

Williams (1956) and Crowell and Susuki (1959) demonstrated a general decrease in grain size westward, suggesting that primary source areas were to the east, although local coarse debris also was contributed from the south and north, suggesting an east-west trough surrounded by rugged terrain (present orientation). This east-west trough probably resulted from active faulting along the north and south boundaries, and within the trough (Crowell and Susuki, 1959; Advocate et al., 1988). This conclusion is demonstrated by the fact that westward along the east-west high-angle fault between $\mathrm{Mg}$ and $\mathrm{Tm}$ southwest of the northeast end of section D-D' (Fig. 3), Tm megabreccia occurs north of the fault and Tm mudrock/sandstone south of the fault, and still farther west, the fault is overlapped by Tm mudrock/sandstone.

Advocate et al. (1988) integrated all of these observations into a submarine-canyon model to explain deposition of the Maniobra Formation. They recognized the following facies: (1) basal transgressive unit of nonmarine grus and shallow-marine conglomerate and sandstone, (2) overlying slope mudstone, and (3) submarine-canyon deposits of mudrock, sandstone and conglomerate. Locally, basal submarine-canyon conglomerate sits in buttress nonconformity of up to $50^{\circ}$ on granite (Advocate et al., 1988). The submarine-canyon deposits are dominantly mudrock, with abundant channel deposits, slump deposits and truncated beds (Advocate et al., 1988). Arenaceous foraminifer indicate local water depths of middle bathyal and deeper in the western part of the canyon, with shorelines to the east and north; most of the southern margin of the submarine canyon is covered by the Diligencia Formation (Advocate et al., 1988).

\section{MIOCENE DILIGENCIA FORMATION}

Williams (1956) was the first to map the Miocene nonmarine strata (informally designated the Canyon Spring formation) unconformably overlying the Maniobra Formation (informally designated the Shaver formation). Williams (1956) documented that northern exposures of the nonmarine strata consist of conglomerate, sandstone, mudrock, limestone, and volcanic rocks; that the strata are at least $1300 \mathrm{~m}$ thick; that the strata are folded into eastwest-trending folds and cut by several sinistral NE-SW faults; and that the sedimentary strata probably were deposited on coalescing alluvial fans and floodplains, with complex facies. Resistant layers of sandstone, limestone and conglomerate form hogbacks and cuestas (Gillies, 1958). Crowell (1960) summarized general characteristics of the 1500 -m-thick nonmarine strata, and suggested that they were Oligocene. Crowell (1973) reported K-Ar ages of 22 and 20 Ma from volcanic and hypabyssal rocks in the Diligencia Formation, consistent with identification of a Lower Miocene vertebrate fossil by Woodburne and Whistler (1973).

Spittler and Arthur (1973), Arthur (1974) and Spittler (1974) provided the first detailed studies of the Diligencia Formation, as summarized by Spittler and Arthur (1982). Crowell (1975b) formally defined the Diligencia Formation in the Canyon Spring area along the east side of the exposures shown in Figure 3, but included strata from throughout the Diligencia basin. Spittler and Arthur (1982) summarized the age, stratigraphy, sedimentology, petrology, and structure of the Diligencia Formation, and presented a detailed geologic map. Squires and Advocate (1982) produced a detailed map and sedimentologic study of the Canyon Spring area. Spittler and Arthur's (1982) stratigraphic units (members) (Td1, Tdv, Td2, Td3 and Td4) were adopted by Law et al. (2001) and during the present study (Fig. 3), although we added Td0 along the northern outcrop margin. Spittler and Arthur (1982) compiled measured sections $\sim 1500 \mathrm{~m}$ thick, but suggested that the original composite thickness might have been $1850 \mathrm{~m}$ to $2000 \mathrm{~m}$

\section{Basal Diligencia Formation}

\section{Southern Margin}

The base of the Diligencia Formation sits nonconformably on Proterozoic augen gneiss and related units along the southern basin boundary and is overlain by basalt-flow units
(Tdv) (Spittler and Arthur, 1982; Squires and Advocate, 1982) (Fig. 3); augen-gneiss clasts dominate the basal part of the basal member (Td1), but clasts of anorthosite, gabbro, syenite and Lowe-type plutonic rocks indicate the presence of a highland to the south, where these rock types are found south of the Clemens Well fault (Crowell, 1993). Sedimentary structures, paleocurrents, clast types and stratigraphic relations suggest that $\mathrm{Td} 1$ consists primarily of alluvialfan, braided-fluvial, deltaic, shoreline and lacustrine deposits derived from uplifted augen gneiss and related crystalline units along the south side of the basin (Spittler and Arthur, 1982; Squires and Advocate, 1982). We suggest that the southwest margin of the basin during its early history was the hangingwall side of the half graben that was tilting down toward the northeast.

\section{Western Margin}

At the base of the northwesternmost exposures of the Diligencia Formation (Fig. 3), up to $60 \mathrm{~m}$ of granitic breccia (Td3) lie nonconformably on Mesozoic granite (Mg) (Gillies, 1958; Spittler and Arthur, 1982). These basal deposits are overlain by arkosic redbeds $~ 200$ $\mathrm{m}$ thick; interbedded breccias of $\mathrm{Td} 3$ are dominantly granitic toward the west, with dilution by gneiss, volcanic rock, and red sandstone clasts to the east (Gillies, 1958). Crowell (1993) interpreted these breccias as being deposited as debris flows or landslides derived from the north from nearby steep slopes. We interpret the basal granitic breccias as representing debris-flow deposits because they dominantly comprise mud-matrix-supported breccias (e.g. Smith and Lowe, 1991; Coussot and Meunier, 1996) derived directly from underlying $\mathrm{Mg}$. In contrast, the interbedded granitic breccias near the top of $\mathrm{Td} 3$ along cross section A-A' (Fig 3) primarily consist of crackle breccia (e.g., Yarnold and Lombard, 1989; Yarnold, 1993; Ingersoll et al., 1996), with clasts possibly more than $6 \mathrm{~m}$ long (Gillies, 1958). We suggest that these crackle breccias were deposited as massive landslides (e.g., Yarnold and Lombard, 1989; Yarnold, 1993) derived from Mg directly north of the deposits during southward tilting of this block during down-to-the-north slip along the Orocopia Mountains and Clemens Well detachment faults.

Williams (1956), Crowell (1975b) and Law et al. (2001) showed a south-dipping normal fault between $\mathrm{Mg}$ to the north and $\mathrm{Td}$ to the south along the south side of the largest granitic outcrop in the northwestern part of the Diligencia basin (Fig. 3; cross section B-B'). The outcrop trace of the "fault" is arcuate and Law et al. (2001) stated that the "fault" surface is nearly horizontal, with gentle dip toward the 
basin. Our investigation of this area revealed no compelling evidence for a fault, and we interpret the contact of the base of Td1 as nonconformable on $\mathrm{Mg}$ (Fig. 3). We concur with Spittler and Arthur (1982) that Td1, Tdv, and $\mathrm{Td} 2$ are found in this location, and that they likely pinch out to the north against $\mathrm{Mg}$ and to the northwest beneath $\mathrm{Td} 3$.

\section{Northern Margin}

Williams (1956) noted that the northern basal conglomerate of the Diligencia Formation (our Td0) thins from $\sim 120 \mathrm{~m}$ in the east to $\sim 30$ $\mathrm{m}$ in the west (Fig. 3); he also noted that conglomerate clast size decreases westward (Figs. 4 and 5) and that the dominant granitic clasts are diluted by gneiss westward (Fig. 6). He suggested sources in the Hayfield Mountains to the north. The sandstone matrix for the conglomerate consists almost entirely of granitic rock fragments, quartz, feldspar and accessory minerals (Williams, 1956). Davisson (1993) (summarized by Law et al., 2001) measured more than $100 \mathrm{~m}$ of basal conglomerate/breccia (our Td0), overlain by more than $360 \mathrm{~m}$ of sandstone (Td1) in the northeastern part of the basin (Fig. 3).

Spittler and Arthur (1982; their fig. 3) inexplicably denoted the base of the Diligencia Formation along the northern exposure, where it sits unconformably on the Maniobra Forma- tion, as Qoa (Quaternary terrace gravels and sands) in spite of the fact that Williams (1956), Crowell and Susuki (1959), Crowell (1962, $1975 b)$ correctly mapped the angular unconformity between the Maniobra and Diligencia formations. Spittler and Arthur's (1982) mistake was retained by Law et al. (2001; their fig. 3 ), in spite of the fact that one of the coauthors (Davisson et al., 1992; Davisson, 1993) studied these same deposits and correctly mapped them as basal Diligencia. Our mapping verified that the basal Diligencia Formation (Td0 on our Fig. 3, so designated in order to retain Spittler and Arthur's [1982] members) dips to the south, in slight angular unconformity on the Maniobra Formation, and is overlain by alluvial red beds (Td1).

In contrast to Spittler and Arthur's (1982) map, their description of the basal Diligencia Formation along the northern outcrop boundary is consistent with our interpretations. They suggested that the northern margin of the basin resulted from faulting, whereas the southern margin was gentler. Rather than an east-west fault(s) along the northern margin (as suggested by Spittler and Arthur, 1982), we suggest that the primary half-graben-bounding fault trends northwest-southeast (see below). The dominant clast type in the northern exposure of $\mathrm{Td} 0$ is granite, with few clasts derived from the Maniobra Formation, consistent with derivation almost exclusively from an uplifted faulted basin margin of granite. We agree with Law et al. (2001) that Td0 and Td1 were deposited on high-gradient alluvial fans derived from a fault escarpment.

Grain size of basal conglomerate. The means of the maximum diameters of the 10 coarsest clasts were determined at 44 sites of $\mathrm{Td} 0$ and part of Td 1 west of and adjacent to Red Canyon (Table 1 of Data Repository [see footnote 1]; Figs. 4 and 5). The largest mean clast size (163.5 cm; DL-30) occurs in the western part of the Td0 exposure, but the greatest concentration of large clasts is in the northeast. Starting from the northeastern exposure of $\mathrm{Td} 0$, there is a regular decrease in clast size toward the west, but this trend is interrupted by the cluster of coarse clasts just to the east of DL-30. Clast size significantly decreases west of DL-30. All measurements along the north side of the Td0 exposure are from within $100 \mathrm{~m}$ of the base of Td0, whereas measurements at the east edge of the Td0 exposure and into Td1 along Red Canyon (Fig. 4) are from higher stratigraphic levels toward the south. Clast size decreases up section along this trend.

The clast size trends probably result from sedimentation on an alluvial fan heading near the northeast limit of $\mathrm{Td} 0$ exposure, and one or

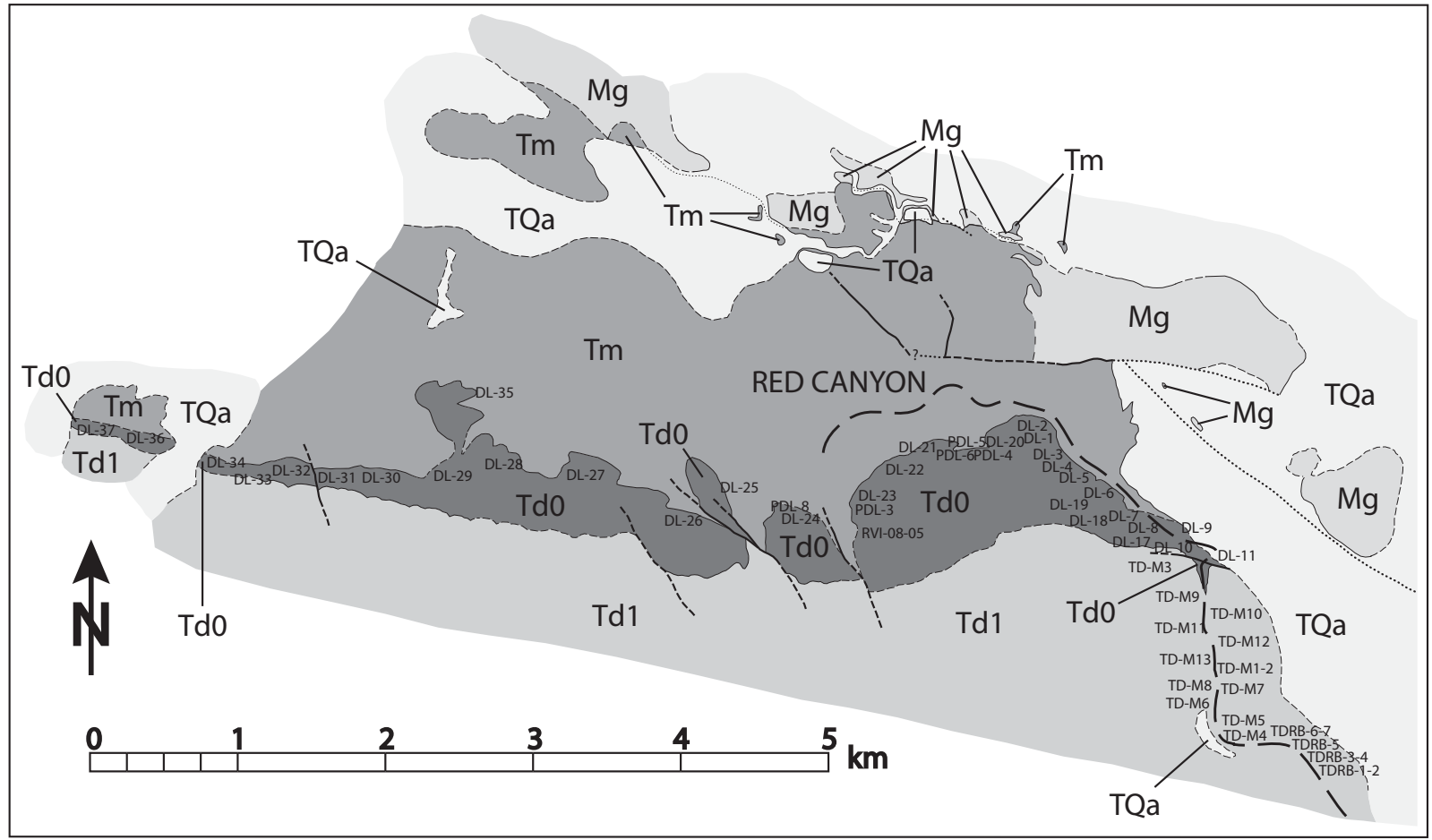

Figure 4. Map of sample locations of Td0 and Td1 along the northern margin of Diligencia basin in the area of Red Canyon (main drainage indicated by heavy dashed line). Base map simplified from Figure 3. 


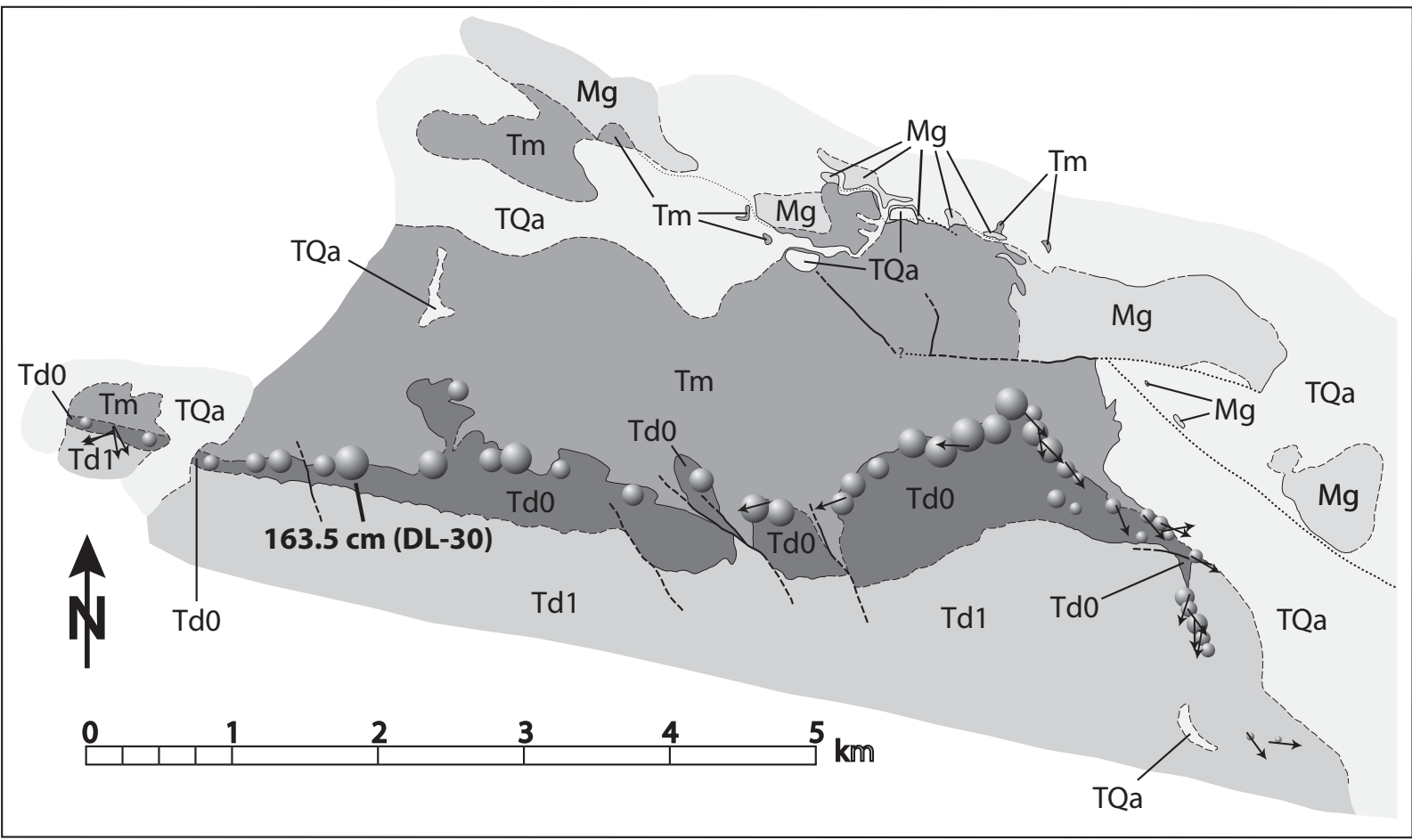

Figure 5. Map of clast size and paleocurrents of Td0 and Td1 conglomerate in Red Canyon area (see Figs. 3 and 4). Mean diameter of 10 coarsest clasts $(\mathbf{c m})$ indicated at each site (see Table 1 of Data Repository; see footnote 1). Mean diameters are scaled to the largest sphere, representing $163.5 \mathrm{~cm}$ (DL-30). Paleocurrent vectors indicated where measured (see Table 2 of Data Repository). Each vector represents the mean direction of 10 imbrication measurements, following restoration of bedding to horizontal and calculation of vector means using method of Potter and Pettijohn (1977). Base map simplified from Figure 3.

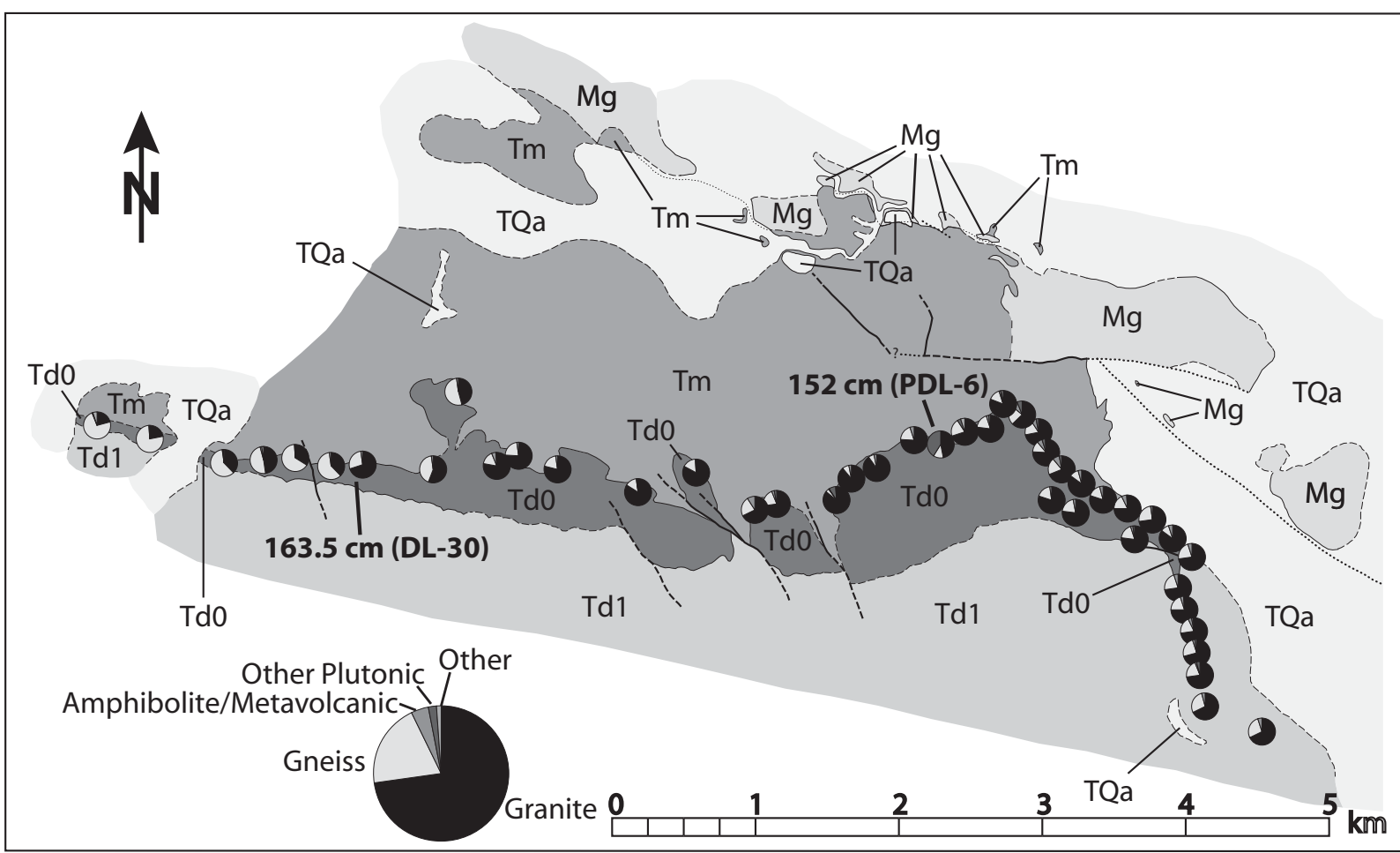

Figure 6. Clast composition of Td0 and Td1 conglomerate (see Table 3 of Data Repository; see footnote 1). Granitic clasts (black) dominate, with subordinate gneiss clasts (light gray). With the exception of PDL6, all other components are subordinate to granitic and gneiss clasts. Base map simplified from Figure 3. 
two smaller alluvial fans heading to the north and/or northeast of the western exposures of Td0. Southeastward and upsection decrease in clast size suggests waning of tectonic activity that uplifted source areas to the northeast during Td0 to Td1 deposition.

Imbrications of basal conglomerate. Where imbricated conglomerate clasts were exposed, orientations of maximum cross-sectional areas of 10 clasts at a given site were measured using Brunton compasses; local bedding orientations were also recorded. A stereonet was used to restore bedding to horizontal, with clast orientations being rotated accordingly. Mean paleocurrent vectors were calculated for each site using the trigonometric grouped-data method of Potter and Pettijohn (1977) (Table 2 of Data Repository). Resulting paleocurrent vectors suggest a radial pattern away from the northeastern corner of the outcrop (Fig. 5). A lack of exposed imbrications characterizes the western half of the Td0 outcrop, with the exception of four exposures at the west end; these four results suggest a southward radiating pattern.

Composition of basal conglomerate. The dominance of granitic composition of both conglomerate and sandstone indicates that the informally named Hayfield granite north and east of the Diligencia basin was the primary source rock. Conglomerate composition was determined by counting 100 clasts at each of 44 sites within Td0 (Table 3 of Data Repository; Fig. 6). Thirty-four of the 35 sites along the eastern two-thirds of the outcrop belt consist of greater than $62 \%$ granite clasts, with a high of $90 \%$. Eight of the nine sites at the western end of the outcrop belt consist of less than $57 \%$ granite, with a low of $21 \%$. Most of these western sites are dominated by gneiss clasts $(28 \%-77 \%)$. These relationships can be interpreted as representing two distinct source areas, granite in the eastern two-thirds and gneiss in the western third. However, there is a positive correlation between granitic composition and grain size (compare Figs. 5 and 6), with granitic clasts tending to be coarser than gneiss clasts. Notice that site DL-30 is the only western site with a majority of granite clasts, and it also contains the coarsest mean grain size $(163.5 \mathrm{~cm})$ of any site. On the other hand, the only eastern site with less than $50 \%$ granite (PDL-6) consists of coarse clasts $(152 \mathrm{~cm})$. It should also be noted that PDL-6 only contains $12 \%$ gneiss and is the only site with significant (41\%) "other plutonic rocks." These "other plutonic rocks" are generally granitoid, so their distinction may not be significant.

Paleogeography. Intersection of a buried Miocene NW-SE-trending normal fault with an Eocene E-W-trending high-angle fault may have created a canyon that funneled coarse granitic detritus to the head of the main alluvial fan (Fig. 7); the E-W-trending fault may have acted as an accommodation zone. Northwest of this intersection, the normal fault displacement merged into a NW-SE-trending monocline that fed smaller fans to the southwest. Finer grain size to the west might also be explained by the fact that the western Td0 outcrop belt is farther from the fault-monocline trend than is the eastern belt. In any case, three coalescing alluvial fans are suggested by the combined clast-size, compositional and imbrication data, as well as the overall paleotectonics and paleoenvironments (Fig. 7).

\section{Volcanic Member}

Williams (1956) and Gillies (1958) described a 3-m-thick porphyritic-andesite flow rock in northern parts of the Diligencia basin; Williams (1956) noted that this single bed overlies sandstone, siltstone and limestone within a $3 \mathrm{~km}$ distance, indicating diverse sedimentary environments prior to eruption. Above the basal member (Td1), olivine-tholeiitic-basaltic flow units up to $160 \mathrm{~m}$ thick (Tdv) are found in the southeastern part of the outcrop belt, with thinning to the north and west; a few clinopyroxene-orthopyroxene andesitic flows and sills are

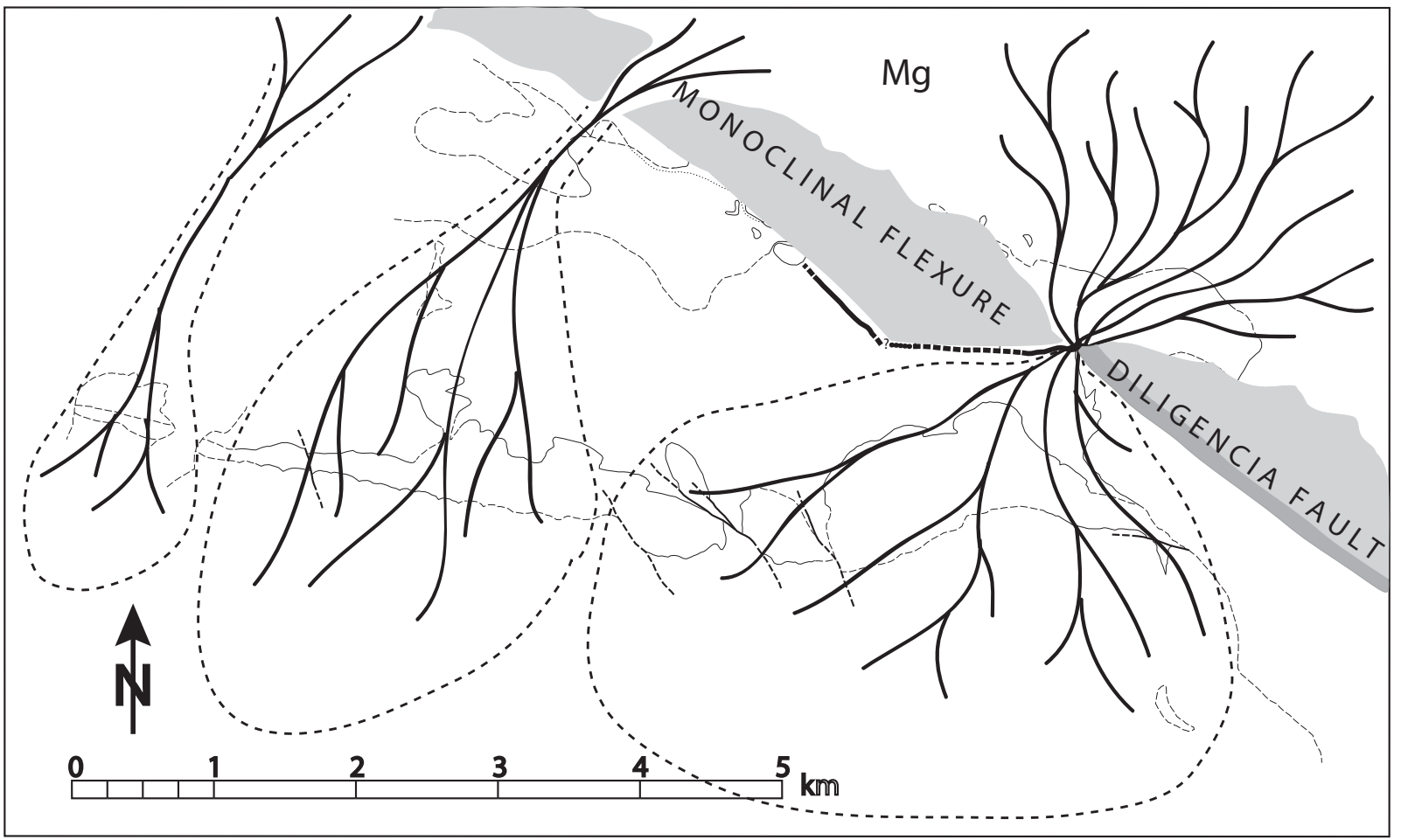

Figure 7. Schematic paleogeographic diagram of alluvial fans that deposited Td0 in northeastern Diligencia basin, based on measurements summarized in Figures 5 and 6. See text for discussion. Base map simplified from Figure 3. 
found above and within Tdv (Spittler and Arthur, 1982). The tholeiitic-basalt eruptions likely resulted from regional extension that formed the Diligencia basin (Spittler and Arthur, 1982).

Volcanic eruption and intrusion were shortlived, based on the thinness of volcanic strata and interbedded sediment (Spittler and Arthur, 1982; Squires and Advocate, 1982); reliable K-Ar ages range from $23.6 \pm 0.5-21.3 \pm 0.6 \mathrm{Ma}$ (Frizzell and Weigand, 1993). Thin lenses of nonmarine limestone containing freshwater ostracodes are locally interbedded with basaltic flow rock; spring-tufa deposits and pillow basalts testify to the interaction of magma and water (Spittler and Arthur, 1982; Squires and Advocate, 1982).

\section{Middle and Upper Diligencia Formation}

Most of the middle and upper Diligencia Formation (Td2, $\mathrm{Td} 3$, and $\mathrm{Td} 4)$ consists of arkosic sandstone and mudrock, with local conglomerate, tuffaceous beds, limestone and evaporitic deposits (Spittler and Arthur, 1982). Spittler and Arthur (1982) suggested that the dominant source of most of the middle and upper Diligencia Formation was the Hayfield granite and related units north and northwest of the Diligencia basin (Fig. 3), based on paleocurrent measurements, clast sizes and clast compositions. $\mathrm{Td} 2, \mathrm{Td} 3$, and $\mathrm{Td} 4$ vary in thickness, as illustrated by pinch out of $\mathrm{Td} 2$ near the Clemens Well fault and deposition of $\mathrm{Td} 3$ directly on $\mathrm{Mg}$ near the northwestern limit of Diligencia exposures (Fig. 3). Anorthosite and related clasts, also derived from the south across the Clemens Well fault, are common in some parts of Td2 (Spittler and Arthur, 1982).

The dominance of granitic clasts and southto-southeast paleocurrents in $\mathrm{Td} 3$ and $\mathrm{Td} 4$ (Spittler and Arthur, 1982) indicate that these members were derived primarily from Mesozoic granite exposed north and northwest of $\mathrm{Td} 3$ and Td4 exposures (Fig. 3). The majority of $\mathrm{Td} 2$ and $\mathrm{Td} 4$ accumulated within lacustrine environments and on distal alluvial fans, whereas the majority of $\mathrm{Td} 3$ represents alluvial-fan deposition (Spittler and Arthur, 1982). Reactivation of faults bounding the granitic horst at the northwest margin of the Diligencia basin (Fig. 3 and cross sections discussed below) likely provided a rejuvenated source for alluvial fans constituting Td3.

Williams (1956), Gillies (1958) and Spittler and Arthur (1982) described multiple dacitic vitric tuffs within the center of the Diligencia basin in strata overlying Tdv. Ebert (2004) acquired a ${ }^{40} \mathrm{Ar} /{ }^{39} \mathrm{Ar}$ sanidine inverse-isochron age of 22.5 $\pm 0.5 \mathrm{Ma}$ and a zircon concordia-curve age of $20.5 \pm 2.2 \mathrm{Ma}$ from an ash bed near the top of the Diligencia Formation (Td4).

\section{Thickness Trends}

Spittler and Arthur (1982) suggested that all Diligencia members thin to the west, except for Td4. Our mapping and stratigraphic sections (Figs. 3, 8, and 9) support this hypothesis for $\mathrm{Td} 0, \mathrm{Td} 1, \mathrm{Tdv}$ and $\mathrm{Td} 2$, but relations for $\mathrm{Td} 3$ and $\mathrm{Td} 4$ are ambiguous because of truncation by the Clemens Well fault and nonpreservation of these members to the east. Spittler and Arthur (1982) stated that Td2 thins to the north and Td3 thins to the south; these observations could indicate that the boundary between $\mathrm{Td} 2$ and $\mathrm{Td} 3$ is defined by facies changes that result in irregular member thicknesses.

Davisson (1993) measured five stratigraphic sections of the basal Diligencia Formation (our Td0 and Td1), which Law et al. (2001) reproduced as their figure 5. We rearranged their three complete sections, along with Squires and Advocate's (1982) Canyon Spring section, so that they are displayed from west to east and north (Fig. 8). The base of each section is an unconformity (nonconformity for three sections along the southern margin and slight angular unconformity on the Maniobra Formation for the northern margin); the top of each section is overlain by basaltic flow rock (Tdv). The three southern sections thicken eastward and the northern section is the thickest. These relations are consistent with early northeastward tilting of the basin during syntectonic sedimentation (see below).

We measured six stratigraphic sections of part of Td2 (Fig. 9), bounded on the base by the top of Tdv, and on the top by the base of a distinctive basin-wide reworked silicic tuff layer, informally name the "wall tuff," based on its vertical exposure just north of Gucci Spring (Fig. 3). This part of $\mathrm{Td} 2$ thickens toward the northeast, again consistent with northeastward tilting during sedimentation. West of the westernmost measured section, the "wall tuff" rests directly on Tdv, indicating that the measured interval has a thickness of zero.

Granitic breccias in $\mathrm{Td} 3$ in the western part of the basin (Fig. 3) thin from a maximum of $150 \mathrm{~m}$ in the northwest to nothing in the southeast, and fine along the same trend (Gillies, 1958; Spittler and Arthur, 1982). This trend may represent cessation of normal faulting along the northeast margin of the basin prior to deposition of $\mathrm{Td} 3$, with subsequent faulting in the west. Lack of preservation of $\mathrm{Td} 3$ and $\mathrm{Td} 4$ over most of the Diligencia basin prevents more definitive conclusions regarding these members.

\section{PLIOCENE/QUATERNARY UNITS}

The eastern and northwestern boundaries of our map area (Fig. 3) are bounded by flat-lying and undeformed sedimentary strata of presumably Pliocene/Quaternary age (Williams, 1956; Spittler and Arthur, 1982). These deposits (TQa) include older alluvium (locally exceeding $10 \mathrm{~m}$ in exposed thickness), terrace deposits of active streams, modern alluvium and colluvium (none of which is differentiated on Fig. 3). Many valleys and flats within the map area also have extensive TQa, which covers several contacts and faults.

\section{SANDSTONE COMPOSITION}

Kirkpatrick (1958) determined the petrography of sandstone of the Maniobra Formation as being dominated by quartz, orthoclase, perthite, plagioclase, biotite, muscovite and granitic rock fragments. Our point counts (Fig. 10; see Caracciolo et al., 2013) confirm these results, which are consistent with derivation from granite, granodiorite and quartz monzonite of the Hayfield Mountains. The sandstone may be characterized as dominantly arkosic arenite (Williams et al., 1954; Crowell and Susuki, 1959).

Williams (1956) and Spittler and Arthur (1982) also characterized Diligencia sandstone as arkosic arenite, dominated by granitic rock fragments, quartz, microperthite, plagioclase and accessory minerals, also consistent with our results from the lower Diligencia Formation from the northern margin (Fig. 10). We did not study sandstone from other parts of the Diligencia Formation.

Caracciolo et al. $(2011,2013)$ presented a complete summary of petrographic results, with an emphasis on the diagenetic evolution of both Maniobra and Diligencia sandstone. For the present study, 35 medium to coarse sandstone samples were thin-sectioned for point counting, 12 from the Maniobra Formation and 23 from the northern lower Diligencia Formation (Td0 and Td1). On average, 500 points were counted for each thin section (etched and stained for plagioclase and potassium feldspars) according to the Gazzi-Dickinson method (Ingersoll et al., 1984; Zuffa, 1985, 1987). Grain parameters and recalculated parameters are those of Dickinson (1970, 1985), Zuffa (1985), and Critelli and Le Pera (1994).

Maniobra sandstone is somewhat richer in quartz than basal Diligencia sandstone from the northern margin (Figs. 10A, 10B), possibly due to more intense weathering during the warmer Eocene (Maniobra deposition) compared to the Early Miocene (Diligencia deposition) (Hall, 2002, 2007; Prothero and Dott, 2002). Alternatively, the slightly higher quartz content of Maniobra sandstone may result from the slightly higher $\mathrm{Rm} / \mathrm{Rg}$ (Fig. 10C). Of course, more intense Eocene weathering may have favored destruction of feldspars over quartz, and granite 


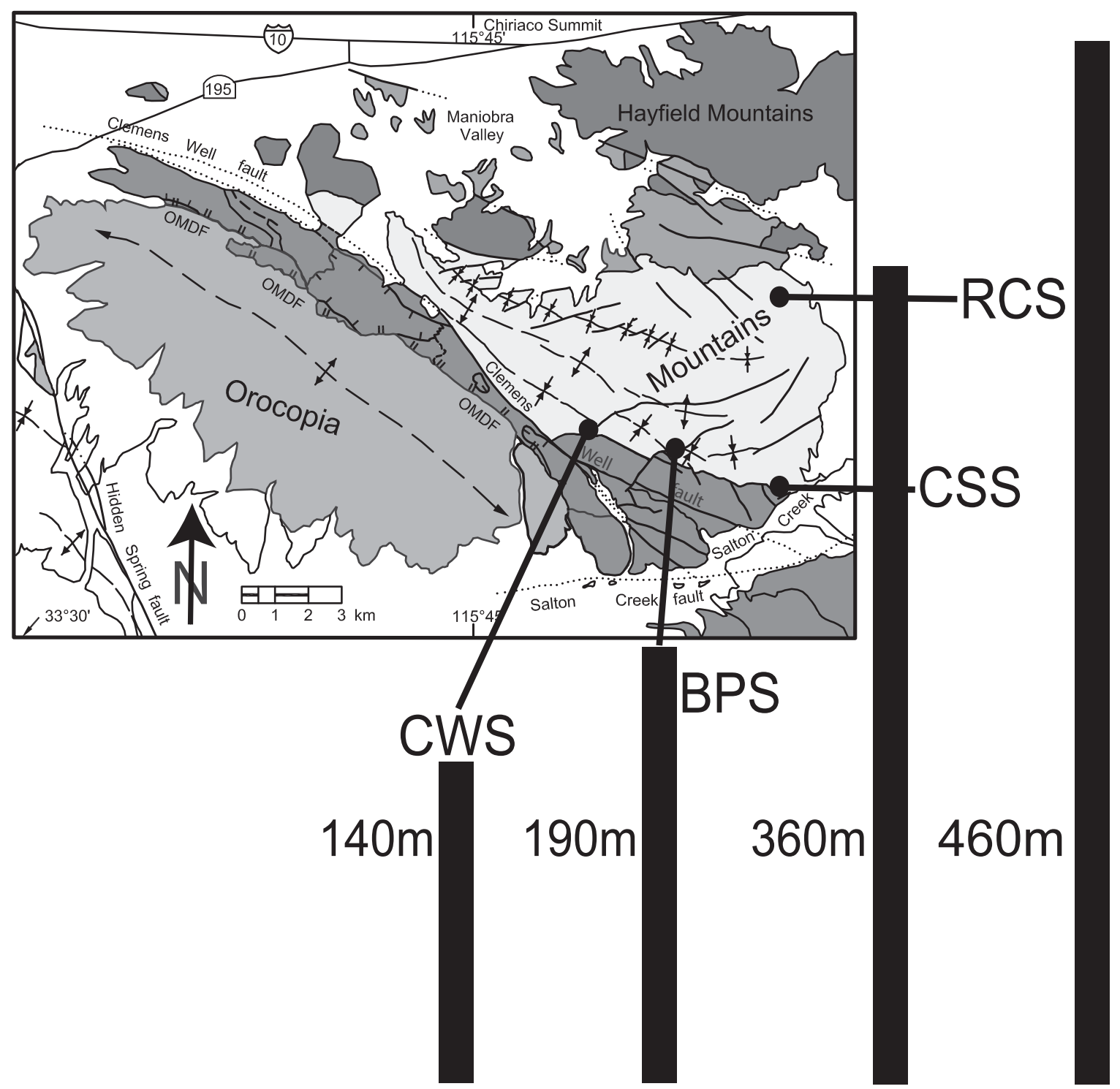

Figure 8. Measured stratigraphic thicknesses of Td0 and Td1 (from underlying unconformity to base of Tdv) (after Squires and Advocate, 1982; Davisson, 1993; Law et al. 2001). CWS-Clemens Well section; BPS-Bullet Peak section; CSS-Canyon Spring section; RCS-Red Canyon section; OMDF-Orocopia Mountains detachment fault. Base map simplified from Figure 2.

over quartzose gneiss, so it is difficult to distinguish source rock versus weathering as controlling factors. In either case, it is clear, based on both conglomerate clast counts (Table 3 of Data Repository; Fig. 6) and sandstone petrography (Fig. 10) that granitic plutonic rocks dominated the provenance, with subordinate gneiss and minor other components.

$\mathrm{Td} 2$ in the southern part of the basin contains plagioclase-rich intervals associated with debris-flow deposits containing anorthosite and related clasts derived from across the Clemens Well fault to the south (Spittler and Arthur, 1982). The only local basement type not represented in any Maniobra or Diligencia conglomerate or sandstone is Orocopia Schist, indicating that exposure of the schist postdated deposition of the Diligencia Formation.

\section{STRUCTURE}

\section{Cross Sections}

Four SW-NE cross sections were constructed based on our compiled map (Fig. 3 ), and three-dimensional constraints of the adjoining cross sections (Fig. 11). Cross sections by Williams (1956), Gillies (1958), and Crowell and Susuki (1959) were consulted for consistency among our map and cross sections, and their observations. Overall, the Diligencia Formation forms a WNW-ESE-trending synclinorium, within which are two major synclines, one major anticline and several smaller folds (Figs. 3 and 11). Along A-A' and B-B' (Fig. 11), a massif of Mesozoic granitoids $(\mathrm{Mg})$ separates exposures of the Diligencia (Td) and Maniobra (Tm) formations. The contact between $\mathrm{Mg}$ and $\mathrm{Td}$ along the southwest side of the massif is herein interpreted as a nonconformity, although others have interpreted it as a low-angle fault (e.g., Williams, 1956; Gillies, 1958; Law et al., 2001). We agree with Williams (1956), and Crowell and Susuki (1959) that Mg is in high-angle fault 


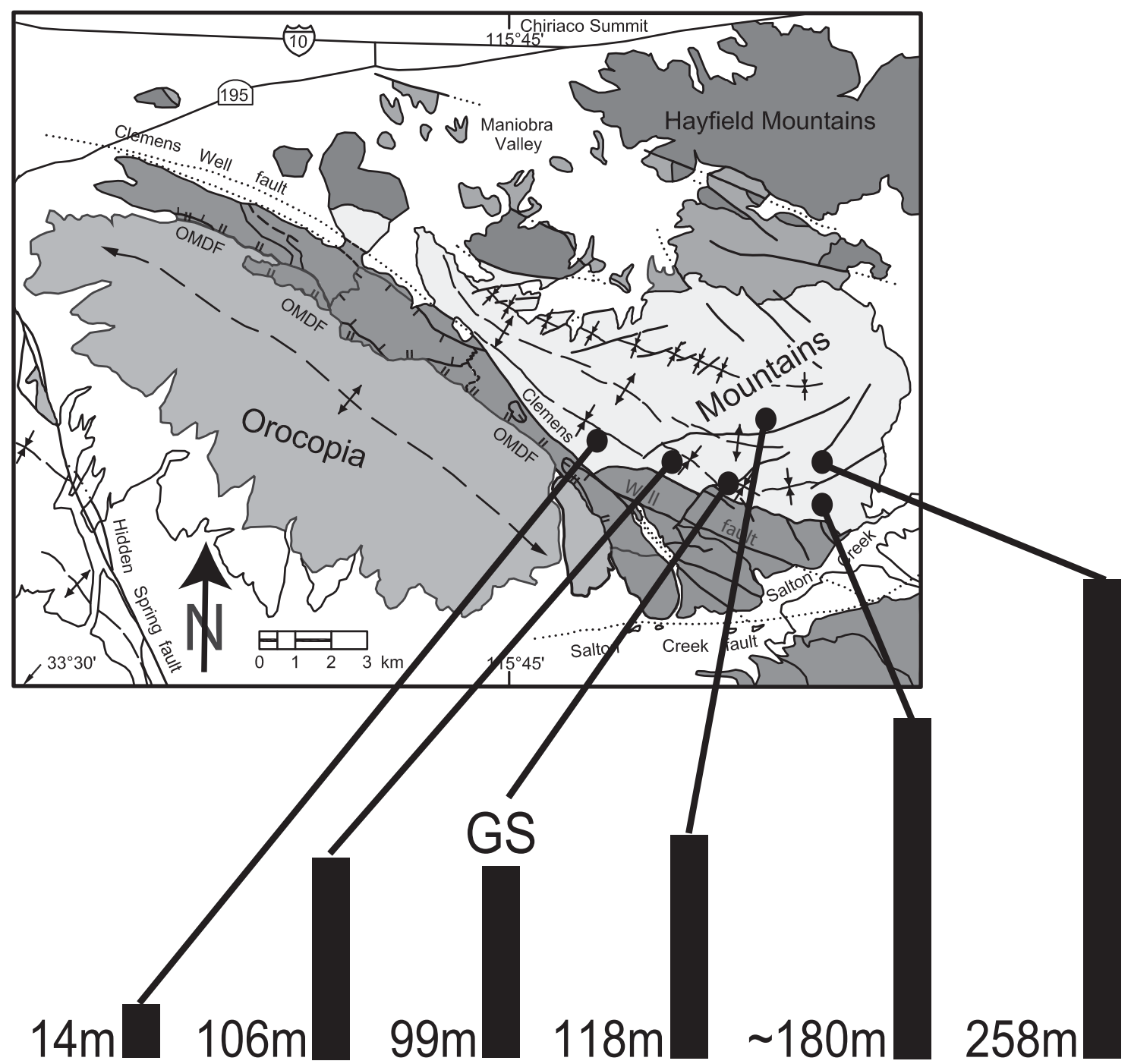

Figure 9. Measured stratigraphic thicknesses of lower part of Td2, from top of Tdv to base of laterally extensive tuffaceous bed (informally called "wall tuff," based on exposure near Gucci Spring [GS]). Base map simplified from Figure 2. OMDFOrocopia Mountains detachment fault.
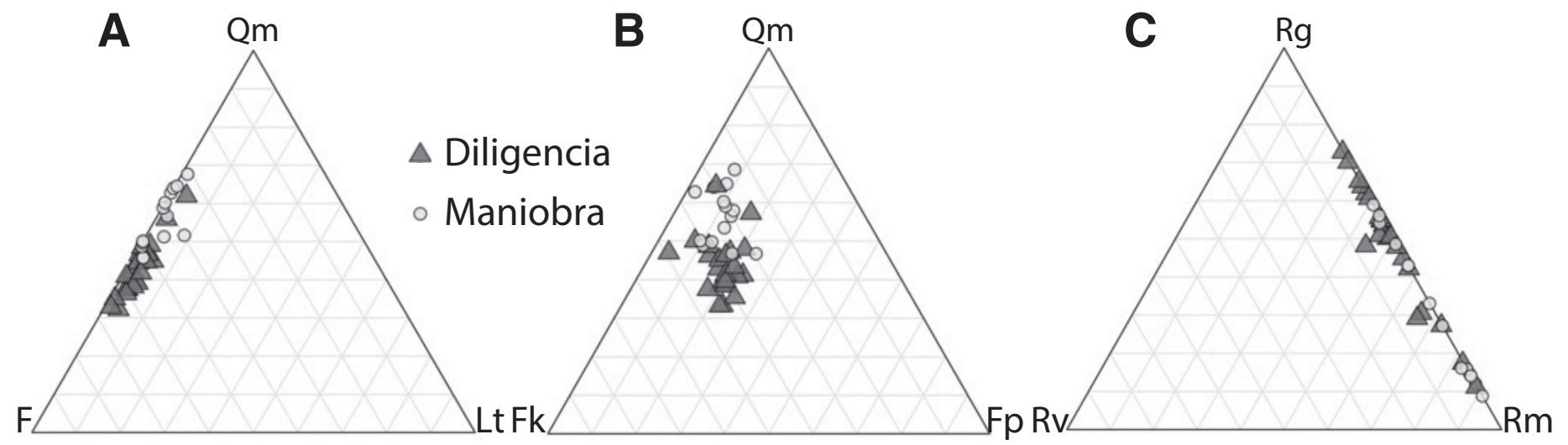

Figure 10. Ternary plots of sandstone composition from Maniobra and Diligencia sandstone from northern basin margin. See Caracciolo et al. (2013) for original and recalculated data. (A) Qm-monocrystalline quartz, F-total feldspar, Lt-all aphanitic lithic fragments. (B) Fk-potassium feldspar, $\mathrm{Fp}$-plagioclase feldspar. (C) $\mathrm{Rg}$-granitic rock fragments, $\mathrm{Rv}$-volcanic/hypabyssal rock fragments, $\mathrm{Rm}$-metamorphic rock fragments. 
contact with Tm along the northeastern margin of the massif. There is a high probability that this fault zone was active during deposition of the Maniobra Formation (see Advocate et al., 1988). Reactivation of this fault zone as a normal fault, synthetic to down-to-the-NE detachment faults that underlie the Diligencia basin, likely occurred in the northwest part of the basin (A- $\mathrm{A}^{\prime}$ in Figs. 11 and 12) late in the history of Diligencia basin, based on the presence of avalanche-breccia deposits in $\mathrm{Td} 3$.

Cross sections $\mathrm{C}-\mathrm{C}^{\prime}$ and $\mathrm{D}-\mathrm{D}^{\prime}$ illustrate similar structural architecture to $\mathrm{A}-\mathrm{A}^{\prime}$ and $\mathrm{B}-\mathrm{B}^{\prime}$, with the exception that the $\mathrm{Mg}$ massif is not exposed; the ESE plunge of the massif may have resulted from Early Miocene tilting toward the NE along the antithetic Diligencia normal fault (see below), resulting in nondeposition of $\mathrm{Td} 0-\mathrm{Td} 2 \mathrm{on} \mathrm{Mg}$ in the northwestern part of the basin (Figs. 3 and 11). Although our interpretation is that reactivation of the $\mathrm{Mg}$-Tm fault only occurred in the northwestern part of the basin (cross section $\mathrm{A}-\mathrm{A}^{\prime}$ ), the $\mathrm{Mg}$ massif might have been a slight topographic high during deposition of $\mathrm{Td} 0$, thus limiting the extent of $\mathrm{Td} 0$ deposition (cross sections $\mathrm{C}-\mathrm{C}^{\prime}$ and $\mathrm{D}-\mathrm{D}^{\prime}$ ). The WNW plunge of the synclinorium (resulting from Neogene shortening) means that lower Diligencia members are exposed primarily in the ESE part of the basin (Figs. 3 and 11).

\section{Restored Cross Sections}

Cross sections A- $\mathrm{A}^{\prime}, \mathrm{B}-\mathrm{B}^{\prime}, \mathrm{C}-\mathrm{C}^{\prime}$ and $\mathrm{D}-\mathrm{D}^{\prime}$ were palinspastically restored, as shown in Figure 12. There are few rigorous geometric constraints for this restoration, but bed thicknesses were mostly conserved, shortening was removed by restoring strata and underlying basement contacts to near horizontal or to their interpreted depositional dip, and crosssectional area was mostly conserved. Some beds within tight folds were unthickened. The resulting highly interpretive cross sections are consistent with the overall model of syndepositional structural development of the basin that involved (present orientations) (Figs. 3, 11, and 12): (1) NE-SW extension along the Orocopia Mountains detachment fault and the Clemens Well (detachment) fault throughout basin development; (2) antithetic listric normal slip along the Diligencia fault during deposition of Td0 and Td1 (thickest to the northeast); (3) sufficient extension to cause decompression melting and eruption to form Tdv (thickest to the southeast); (4) cessation of slip on the Diligencia fault and deposition of Td2 (thickest near center of basin); (5) initiation of synthetic normal slip on the reactivated $\mathrm{Mg}$-Tm fault along the northeastern side of the $\mathrm{Mg}$ massif, result-
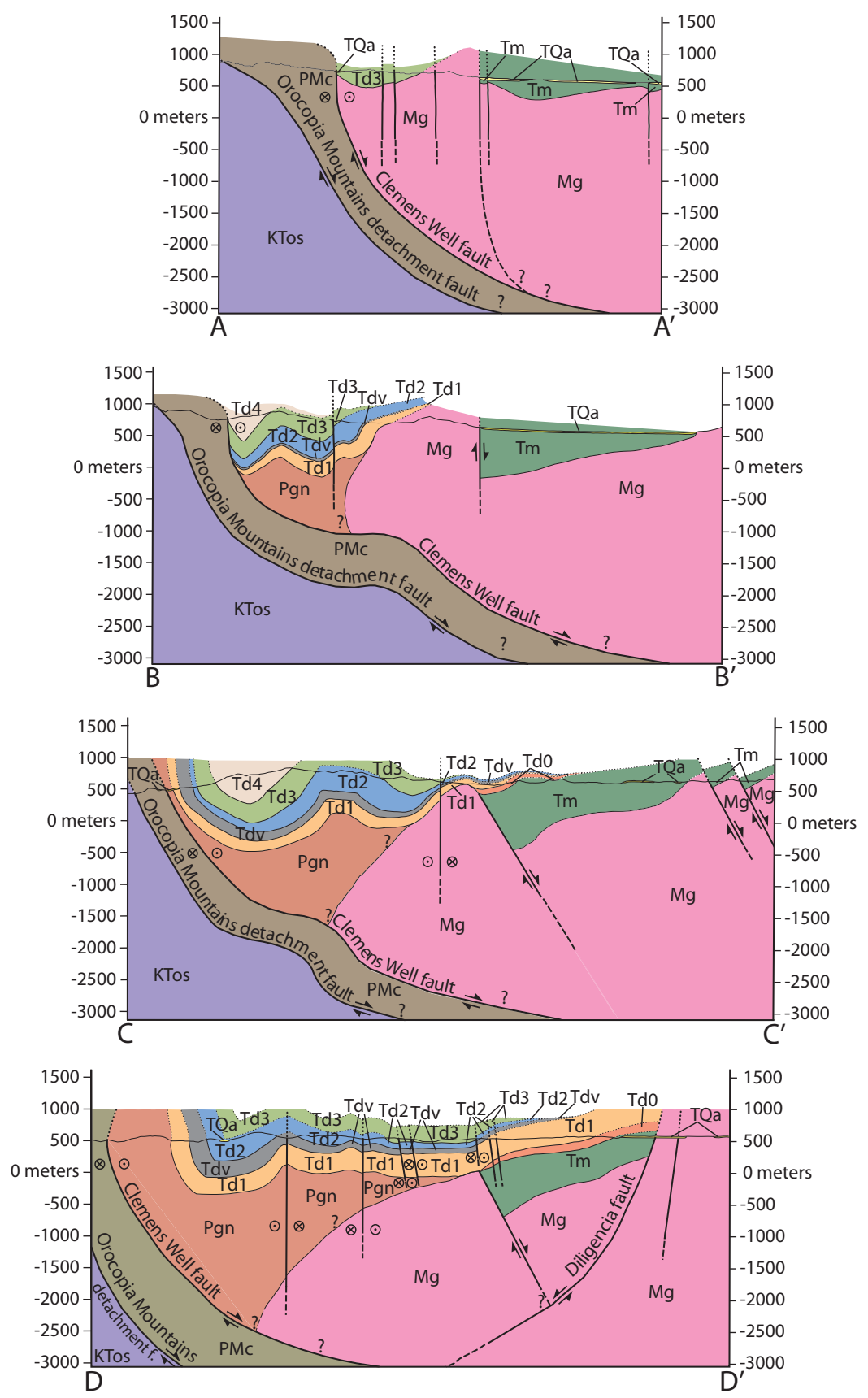

Figure 11. SW-NE cross sections across Diligencia basin. Cross sections are aligned along Mg-Tm fault near center of each cross section. Relations at depth are speculative. Locations and map units indicated on Figure 3.

ing in deposition of $\mathrm{Td} 3$ and $\mathrm{Td} 4$ (thickest to the northwest); and (6) cessation of extensional tectonics and Diligencia deposition.

\section{Pre-Diligencia Faults}

Advocate et al. (1988) proposed that the Maniobra Formation was deposited in a WNWtrending fault-controlled submarine canyon, based on (1) parallelism of faults and paleocur- rents, (2) steep angles of stratal onlap and termination on canyon walls, and (3) proximity of faults to boulder lag deposits and disturbed beds. The best evidence for syntectonic deposition of the Maniobra Formation may be found $2 \mathrm{~km}$ west-southwest of the NE end of D-D' (Figs. 3 and 11), where a high-angle E-W fault juxtaposes $\mathrm{Mg}$ to the north against $\mathrm{Tm}$ to the south. As this fault is traced westward, megabreccias of $\mathrm{Mg}$ north of the fault are difficult 

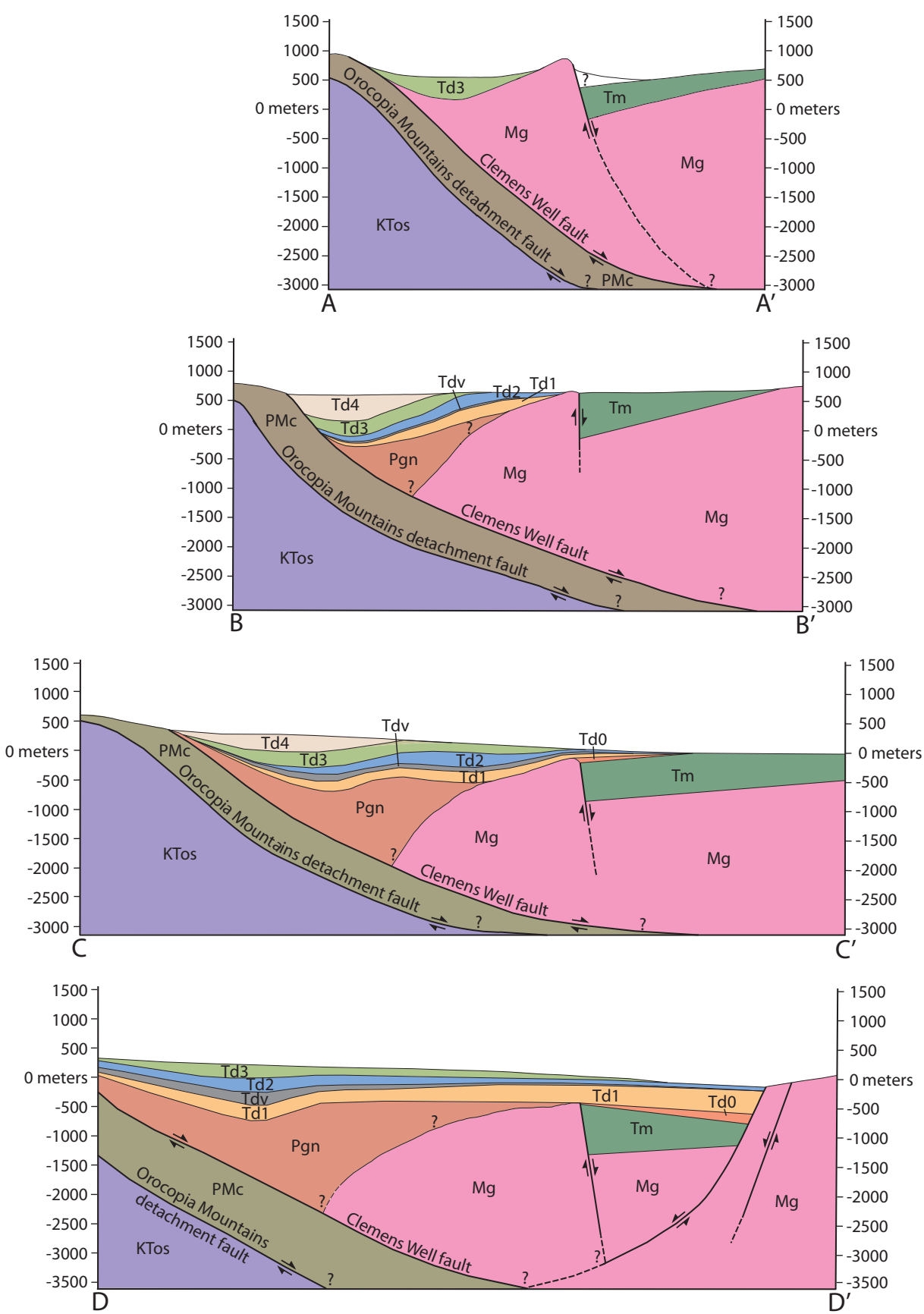

Figure 12. Restored cross sections from Figure 11. Cross sections are aligned along Mg-Tm fault near center of each cross section. Locations and map units indicated on Figure 3.

to distinguish from $\mathrm{Mg}$ to the east; still farther west, the fault separates younger parts of Tm on both sides of the fault. Still farther west, the fault is overlapped by finer-grained Tm. We suggest that movement on E-W high-angle faults that truncate $\mathrm{Mg}$ and $\mathrm{Tm}$ occurred primarily during Maniobra deposition (Eocene). This includes the WNW-trending high-angle faults that bound the NNE sides of the Mg massifs shown in $\mathrm{A}-\mathrm{A}^{\prime}$ and $\mathrm{B}-\mathrm{B}^{\prime}$ (Figs. 3 and 11), and discussed above.

\section{Geological Observations}

Spittler and Arthur (1982) and Law et al. (2001) suggested that the Diligencia half-graben basin resulted from north-south regional extension, resulting in roughly east-trending normal faults, although they were unable to identify specific basin-bounding faults. Granitic breccias in the northwestern exposures of $\mathrm{Td} 3\left(\mathrm{~A}-\mathrm{A}^{\prime}\right)$
(Figs. 3, 11, and 12) probably were derived from rugged topography of a block of $\mathrm{Mg}$ that was tilted toward the SSW as the hangingwall of the Orocopia Mountains detachment fault (OMdf) and Clemens Well fault (CWf), and the footwall of the Mg-Tm normal fault, as discussed above. Robinson and Frost (1996) proposed that the dominant syn-Diligencia fault system was a NE-dipping low-angle detachment system that dropped the Diligencia basin down toward the northeast along several faults exposed between the Orocopia Schist in the lower plate, and diverse Proterozoic and Mesozoic rocks in the upper plate, on top of which the Diligencia Formation accumulated (Figs. 3 and 11). In our model, the low-angle detachment system was the primary way that SW-NE crustal extension was accommodated. The lower Diligencia Formation was deposited in a half graben that tilted to the NE because it was bounded on the NE by an antithetic SW-dipping normal fault; the upper Diligencia Formation was deposited, in part, between the detachment faults and the synthetic Mg-Tm fault.

We herein name the NW-SE-trending antithetic normal fault the "Diligencia fault," most of which is covered by Pliocene-Quaternary alluvium (TQa) (Figs. 3 and 11). Evidence for the Diligencia fault is the following:

1. All outcrops NE of the fault are Mg.

2. All outcrops SW of the fault are either Tm or Td.

3. A SW-dipping $\left(60^{\circ}\right)$ surface of sheared $\mathrm{Mg}$ is exposed at the southern end of the SEmost outcrop of Mg (Fig. 3).

4. The NS canyon at the NW end of the buried Diligencia fault exposes extensively sheared Mg.

5. Farther to the NW along this trend are several NW-trending high-angle faults cutting both $\mathrm{Mg}$ and $\mathrm{Tm}$.

6. Between the $\mathrm{NE}$ ends of $\mathrm{B}-\mathrm{B}^{\prime}$ and $\mathrm{C}-\mathrm{C}^{\prime}$ (and especially $1 \mathrm{~km} \mathrm{SW}$ of a line joining the ends of $\mathrm{B}-\mathrm{B}^{\prime}$ and $\mathrm{C}-\mathrm{C}^{\prime}$ ) is a monoclinal bend in the nonconformity between $\mathrm{Mg}$ and Tm, which may represent the NW tipping out of down-to-the-SW normal displacement (Figs. 3 and 11).

7. Gravity and magnetic surveys are consistent with a NW-SE-striking normal fault, dipping $60^{\circ}$ to the SW and separating sedimentary rock to the SW from granitic rock to the NE.

\section{Geophysical Surveys}

Gravity and magnetic surveys were conducted along 4 profiles across the Diligencia fault in 2009 and 2011. Figures 3 and 13 show locations of the profiles, which were oriented NE-SW, orthogonal to the inferred NW strike of the fault. 


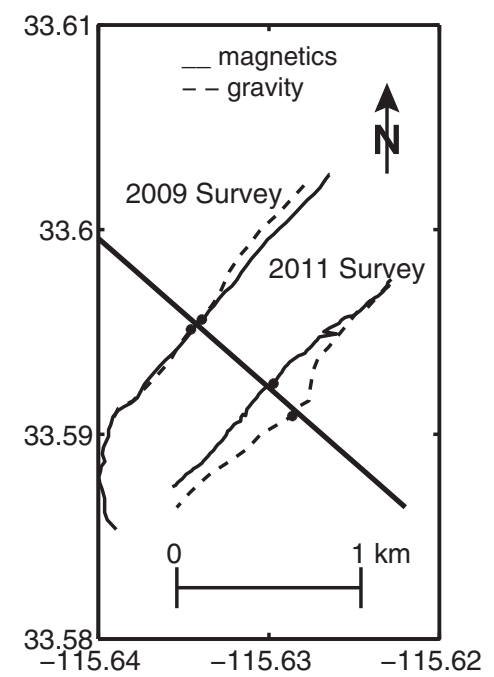

Figure 13. Location map for gravity and magnetic surveys. Dots denote where the 2D model placed the surface contact of the fault from the independent 2D gravity and magnetic modeling. Thick line at right angle to survey lines is a least-squares fit to the $\mathbf{4}$ data points; location agrees with geological estimates of fault location (see Fig. 3).

Gravity. Raw gravity readings were made with a LaCoste Romberg gravimeter and were corrected for drift by repeated measurements at a base station. The measurements were separated by an average spacing of $100 \mathrm{~m}$ along lines $\sim 1.5 \mathrm{~km}$ long (Fig. 14). Elevations and locations were measured using an RTK (real time kinematic) GPS system accurate to a few centimeters. Bouguer anomalies were calculated after applying standard corrections (free air, latitude and Bouguer, with density $2670 \mathrm{~kg} / \mathrm{m}^{3}$ ) and removing a regional linear trend. For both surveys, a step increase of 1-2 mGals in gravity was observed to the NE near the inferred fault trace, where we infer that sedimentary rock is in fault contact with granitic rock.

We modeled the contrast between the sedimentary and granitic rock across the fault using a 2D polygon model (Talwani et al., 1959) with a dipping interface. Locations of survey points were converted to UTM coordinates and the coordinates rotated $51^{\circ}$, so that the rotated $x$-axis lies along the averaged direction of the surveys. We inverted the data for parameters, such as density contrast, location and dip of the interface, using nonlinear least squares. Because of a tradeoff between density contrast and depth, we fixed the depth to $300 \mathrm{~m}$, consistent with cross section D-D' (Fig. 11). We found that a single-polygonal model fit both the gravity and magnetic data sets to within the accuracy of the measurements, but with different density and magnetization con-
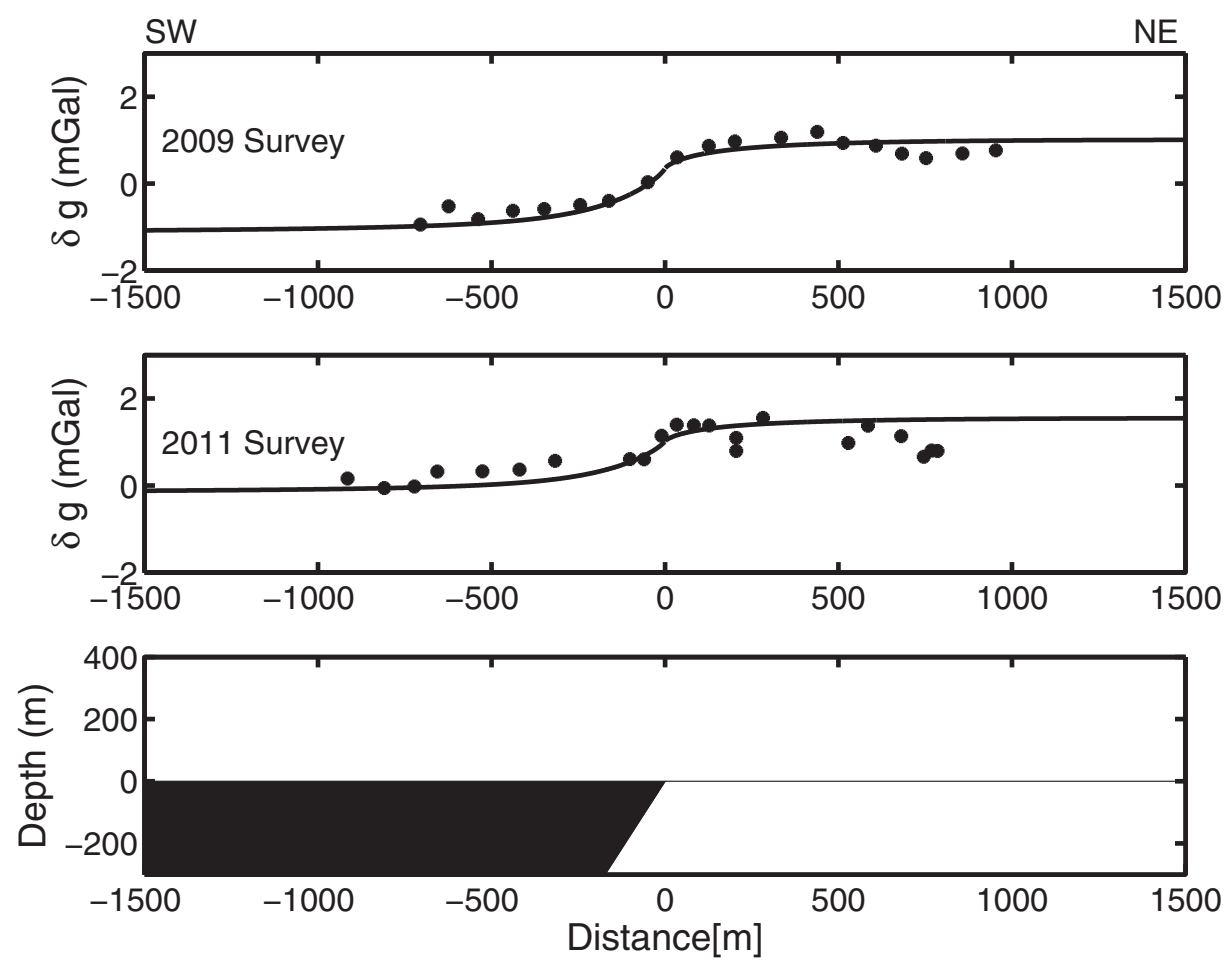

Figure 14. Bouguer-gravity points (dots) and model values (lines) for survey lines in Figure 13. Lines are SW-NE along rotated UTM x-coordinate. While the shape of the increase in gravity measurements is similar for the two surveys, the density contrast is $180 \mathrm{~kg} / \mathrm{m} 3$ and $144 \mathrm{~kg} / \mathrm{m} 3$ for the 2009 and 2011 surveys, respectively. See text for discussion of fault model (bottom).

trasts. For example, the amplitude of the 2009 data $(\sim 2 \mathrm{mGal})$ is greater than that of the 2011 data $(\sim 1 \mathrm{mGal})$, and so the density contrasts are 180 and $144 \mathrm{~kg} / \mathrm{m}^{3}$, respectively.

Magnetics. The raw magnetic data were total-field readings using a Geometrics proton precession magnetometer. A base station recorded the background field, and synchronized magnetic differences were obtained by subtracting base-station readings interpolated to the times of measurement from baseline data. Magnetic readings were taken approximately every $20 \mathrm{~m}$ (Fig. 15). A linear regional trend was removed from the magnetic data. For both surveys, a sharp decrease in the magnetic field is seen at the inferred fault contact.

We used the same geometrical model for the magnetics as for the gravity, but with magnetization contrast rather than density (e.g., Telford et al., 1998). We assumed that the magnetization lies in the direction of the Earth's field (dip $60^{\circ}$ ) (i.e., that it is induced and that the remanent component is negligible). The magnetic contrast adjusted to fit the data on both profiles gives a larger value of magnetization in the sedimentary rock than in the granitic rock, and even greater variability between the surveys (48 and $8 \mathrm{nT}$, respectively) (Fig. 15).
Discussion. All four data sets are consistent with a NW-SE-striking normal fault. The contact points from the gravity and magnetic models for each survey agree and the line through them passes close to that inferred from geologic mapping of isolated exposures of the sedimentary-granitic-rock interface (Fig. 3). Thin sections of samples of the granite $(\mathrm{Mg})$ reveal that it contains no magnetic minerals, consistent with the observation that the sedimentary rock has higher magnetization than the granite.

\section{Post-Diligencia Faults}

Crowell $(1960,1962)$ suggested that the Clemens Well fault experienced modest postDiligencia dextral slip, based on fault slivers of Diligencia Formation with modest dextral separation and the presence of clasts in the upper Diligencia derived from the anorthositegabbro-syenite complex across the fault to the southwest (western edge of Fig. 3). Bohannon $(1975,1976)$ interpreted the Clemens Well fault as initially a normal fault, down to the northeast in present orientation, that was the southwest boundary of the Diligencia half graben, offset across the San Andreas fault from the FennerSan Francisquito fault and associated Charlie 

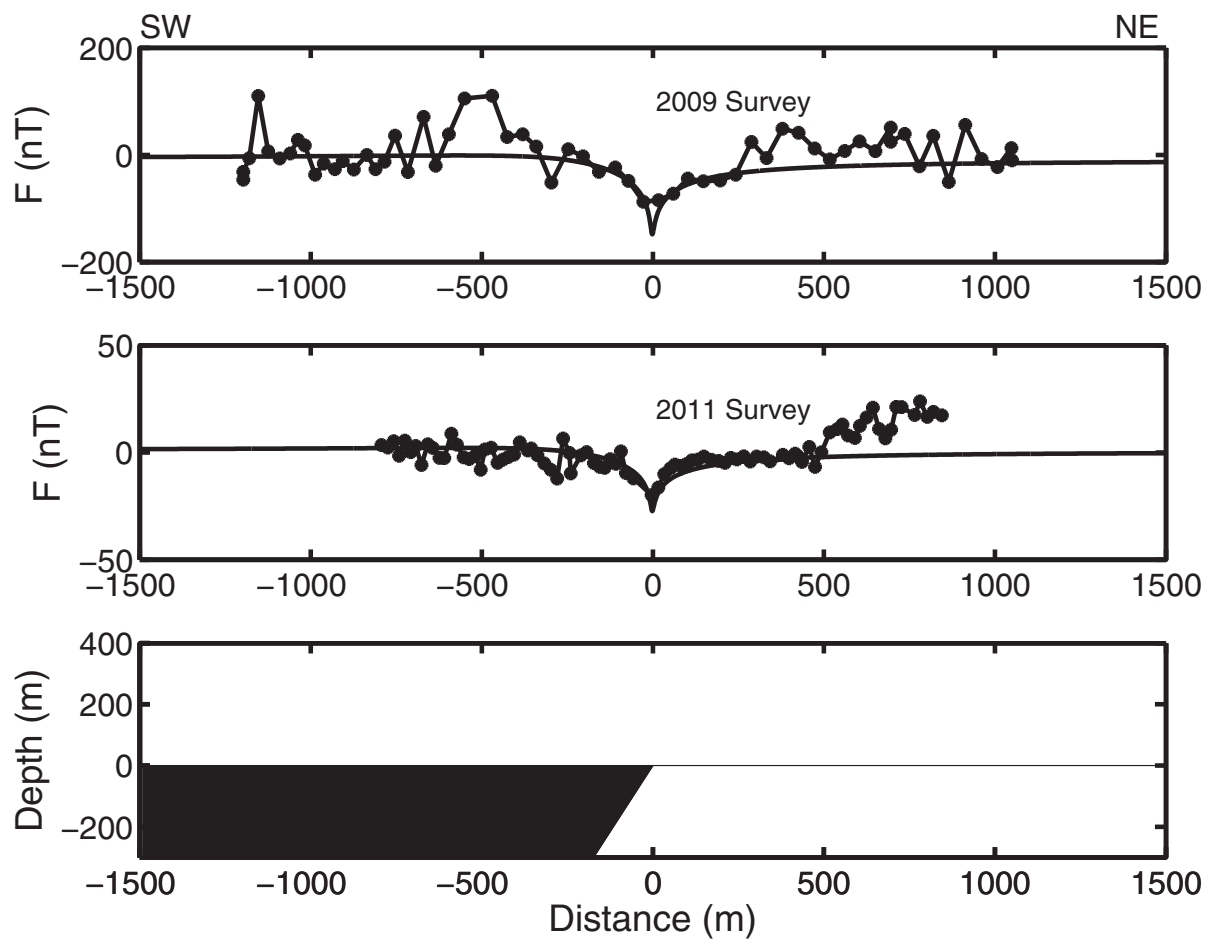

Figure 15. Magnetic-field readings (dots) and model values (lines) for survey lines in Figure 13. Lines are SW-NE along rotated UTM x-coordinate. Polygonal model in lower panel has been fit to the data and has higher magnetization in sedimentary rocks to the SW of the fault compared with that of the granitic rock. Magnetization contrast is $48 \mathrm{nT}$ and $8 \mathrm{nT}$ for the 2009 and 2011 surveys, respectively. See text for discussion of fault model (bottom).

Canyon half graben (see reconstruction below). This interpretation was further developed by Robinson and Frost (1996), who suggested that the Clemens Well fault was one of several NEdipping low-angle normal faults that was later rotated to near vertical and reactivated as a dextral fault; they agreed that dextral slip on the Clemens Well fault had to have been less than a few kilometers, and possibly considerably less. The near parallelism of the basal Diligencia nonconformity and the Clemens Well fault dictates that any movement along the fault that was synchronous with Diligencia deposition had to have been at a low angle, and/or that movement along the fault when it was near vertical only could have occurred following shortening of the Diligencia basin (latest Miocene to Pliocene), which resulted in steepening of the nonconformity to near vertical.

In contrast, Smith (1977), Powell and Weldon (1992), Matti and Morton (1993), Morton and Matti (1993), Powell (1993) and Weldon et al. (1993) argued that dextral slip along the Clemens Well fault had been between 85-175 $\mathrm{km}$ during Early-Middle Miocene (a suggestion that is inconsistent with the near parallelism of the nonconformity and Clemens Well fault, as described above). We favor modest by either transpression along the San Andreas system or north-south shortening of the entire
Mojave region (e.g., Bartley et al., 1990; Law et al., 2001).

Folds

Two synclines and one anticline, trending $\sim 110^{\circ}$ with variable plunges, dominate the structure of the Diligencia basin (Figs. 3 and 11). The southern syncline is the most asymmetric, with a steep to overturned southern limb; fold axes converge toward the Clemens Well fault (Spittler and Arthur, 1982). Folds are tighter and of greater amplitude from north to south, where shortening is concentrated (Figs. 3 and 11) (Law et al., 2001). Smaller anticlines and synclines are found throughout the map area, especially in the southwestern area near the Clemens Well fault.

\section{PALINSPASTIC RECONSTRUCTION}

\section{Reversal of San Andreas Fault Offset}

We removed $\sim 240 \mathrm{~km}$ of dextral slip on the San Andreas fault (including the Punchbowl and related San Andreas faults) in order to bring in close proximity the antiformal exposures of the Orocopia Schist and the Pelona Schist, and to align the San Francisquito, Fenner and Orocopia Mountains-Clemens Well faults (e.g., Crowell, 1975a; Ingersoll and Rumelhart, 1999; Jacobson et al., 2011; and references therein) (Fig. 16A, 17). This slip has occurred since $6 \mathrm{Ma}$ (Nicholson et al., 1994; Ingersoll and Rumelhart, 1999; Oskin et al., 2001; Oskin and Stock, 2003). As Crowell (1975a) pointed out, this reconstruction also brings into proximity: (1) similar diverse Precambrian and Mesozoic crystalline rocks; (2) the uppermost Cretaceous-Paleogene deepmarine San Francisquito Formation (Kooser, 1982) north of Sierra Pelona with the Eocene Maniobra Formation; (3) the Vasquez and Diligencia formations of overlapping ages, similar interbedded volcanic units and similar basin styles; and (4) both low-angle and high-angle faults of similar character. Bohannon (1975, 1976), Tennyson (1989) and Hendrix et al. (2010) refined this reconstruction and proposed more specific correlations (utilized in Fig. 17). We find these correlations compelling, and therefore, reject the reconstructions of Powell and Weldon (1992) and Powell (1993), who proposed far less slip on the San Andreas fault and far more slip on the Clemens Well fault.

\section{Reversal of Shortening}

Law et al. (2001) demonstrated that northsouth shortening (inversion) of the Diligencia basin occurred later than vertical-axis block 

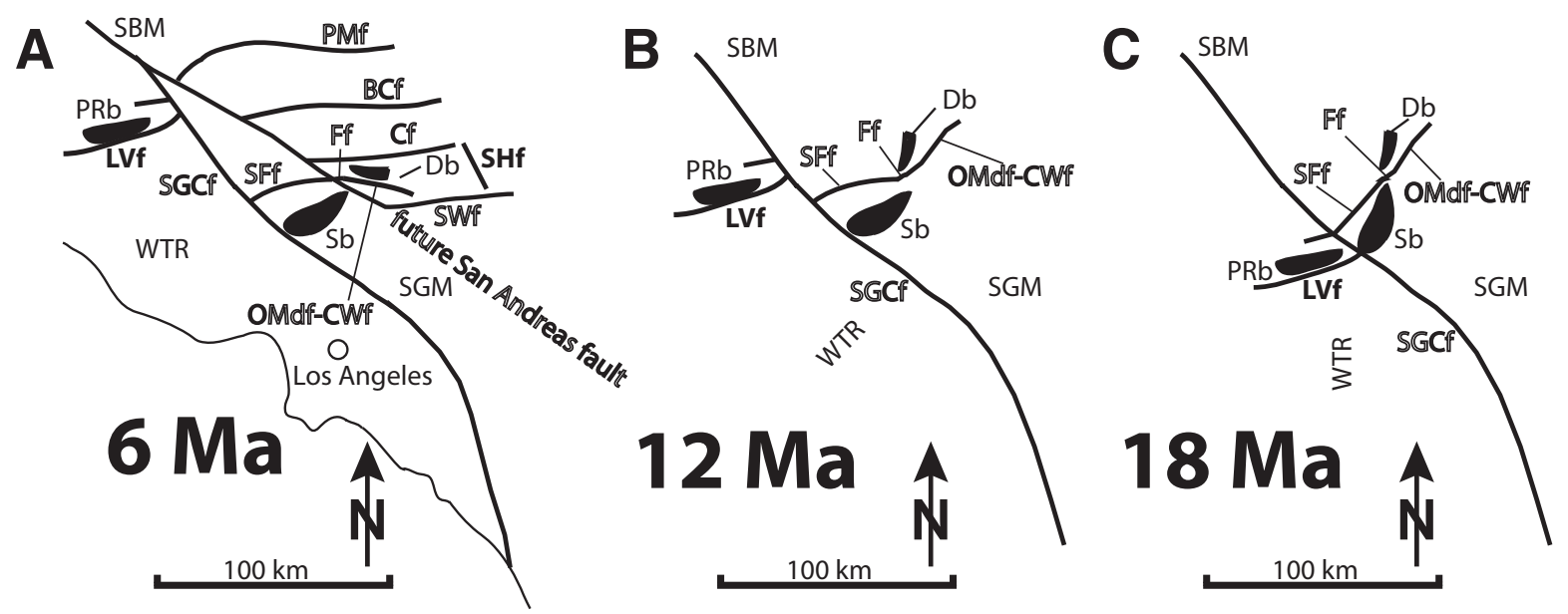

Figure 16. Palinspastic restoration in 3 stages (see Fig. 1 for abbreviations). (A) 6 Ma (San Andreas fault dextral slip reversed) (vertical-axis rotation of eastern Transverse Ranges may not have occurred yet, although it is shown here); (B) 12 Ma (San Gabriel fault dextral slip and eastern Transverse Ranges vertical-axis rotations reversed) (vertical-axis rotation of western Transverse Ranges [WTR] partially reversed); (C) 18 Ma (WTR and Soledad basin vertical-axis rotations, and Canton fault dextral slip reversed). See text for discussion.

rotation (see below), thus bracketing shortening to the latest Miocene to Pliocene. They speculated that this shortening "resulted from the locking, and subsequent internal deformation, of this previously elongate crustal block." (Law et al., 2001, p. 196). Shearing and local rotation adjacent to the Clemens Well fault either accompanied or postdated basin shortening (inversion) (Law et al., 2001), but ceased before the Late Pliocene (Powell, 1993). Our restored cross sections (Fig. 12) demonstrate how reversal of shortening results in basin architecture consistent with deposition of the lower Diligencia Formation in a half graben tilted down to the northeast (present orientation), and deposition of the upper Diligencia Formation on a SW-tilted Mg block bounded by NE-dipping normal faults (both low-angle [below] and high-angle [above]). Shortening by $\sim 25 \%$ is indicated by $3 \mathrm{~km}$ of shortening along the original $12 \mathrm{~km}$ of restored cross section D-D' (Figs. 11 and 12).

\section{Reversal of Vertical-Axis Rotation and San Gabriel Fault Offset}

The Orocopia/Diligencia block is bounded on the north by the Chiriaco fault, on the east by the Sheep Hole fault, on the south by the Salton Wash fault, and on the west by the San Andreas fault (Figs. 1 and 2). Clockwise vertical-axis rotation of $\sim 41^{\circ}$ affected several blocks of the eastern Transverse Ranges between 10 and 4.5 $\mathrm{Ma}$, with the Diligencia basin being rotated $\sim 110^{\circ}$ and rotations of individual blocks of up to $180^{\circ}$ near the Clemens Well fault (Carter et al., 1987; Richard, 1993; Dickinson, 1996; Law et al., 2001). The increase in magnitude of vertical-axis rotation of basalt within the Diligencia Formation from $\sim 110^{\circ}$ to $180^{\circ}$ is best explained by having most of the regional rotation take place prior to local shortening by faulting and folding, which locally increased clockwise rotation (Terres, 1984; Law et al., 2001).

At least partially coincident (12-5 Ma) with clockwise rotation of the Orocopia block, dextral slip of $\sim 40 \mathrm{~km}$ occurred on the San Gabriel fault between the Soledad area and the Plush Ranch area (Crowell, 1975a, 1981, 2003; Hendrix et al., 2010) (Figs. 16A, 16B). Restoration of this slip (plus $\sim 30 \mathrm{~km}$ on the parallel Canton fault; Figs. 16B, 16C) brings Precambrian and Mesozoic crystalline rocks, uppermost Cretaceous-Paleogene deep-marine strata, the Plush Ranch Formation, and high- and low-angle faults into alignment with those of the Soledad and Orocopia areas, as discussed above and by Crowell (1975a), Bohannon (1975, 1976), Tennyson (1989), Hendrix et al. (2010) and Hoyt (2012) (Figs. 16C, 17).

\section{Reversal of Western and Central Transverse Ranges Rotation and Canton Fault Offset}

The Soledad basin is part of the San Gabriel Mountains block (Fig. 1), which has been rotated $\sim 40^{\circ}$ clockwise about a vertical axis (Terres, 1984; Terres and Luyendyk, 1985; Luyendyk, 1991). The uppermost Oligocene/ Lower Miocene Vasquez Formation is rotated $40^{\circ}$, whereas the Middle Miocene Mint Canyon
Formation has not been rotated, thus bracketing the time of clockwise rotation as $18-16$ $\mathrm{Ma} ; 55^{\circ}$ of clockwise rotation occurred at this time, with later counterclockwise rotation of $\sim 15^{\circ}$, resulting in a net clockwise rotation of $40^{\circ}$ (Terres, 1984; Terres and Luyendyk, 1985; Luyendyk, 1991). The western Transverse Ranges have been rotated clockwise more than $90^{\circ}$, beginning around $18 \mathrm{Ma}$ (Luyendyk, 1991; Nicholson et al., 1994; Dickinson, 1996; Ingersoll and Rumelhart, 1999; Ingersoll, 2008a). Figure $16 \mathrm{C}$ shows reversal of clockwise rotation of $40^{\circ}$ for the Soledad area, and reversal of clockwise rotation of $90^{\circ}$ for the western Transverse Ranges. Dextral slip of $\sim 30 \mathrm{~km}$ on the Canton fault (Crowell, 2003) was likely concurrent with these vertical-axis rotations, as shown in Figure 16B and 16C. The Plush Ranch basin north of the Lockwood Valley fault has not been significantly rotated (Onderdonk, 2005).

\section{Reversal of Regional Extension}

Once the above palinspastic corrections are completed, the NW-SE-trending Orocopia Mountains detachment system (Robinson and Frost, 1996; Jacobson et al., 2007), Clemens Well fault and Diligencia fault become NE-SW-trending fault systems (Figs. 16, 17). These NE-SW trends parallel both low-angle and high-angle faults of the Soledad and Plush Ranch basin areas (including the Fenner fault in the Devil's Punchbowl area), following appropriate removal of variable clockwise rotation of these blocks (e.g., Bohannon, 1975, 1976; Tennyson, 1989; Hendrix et al., 2010; Hoyt, 2012). 


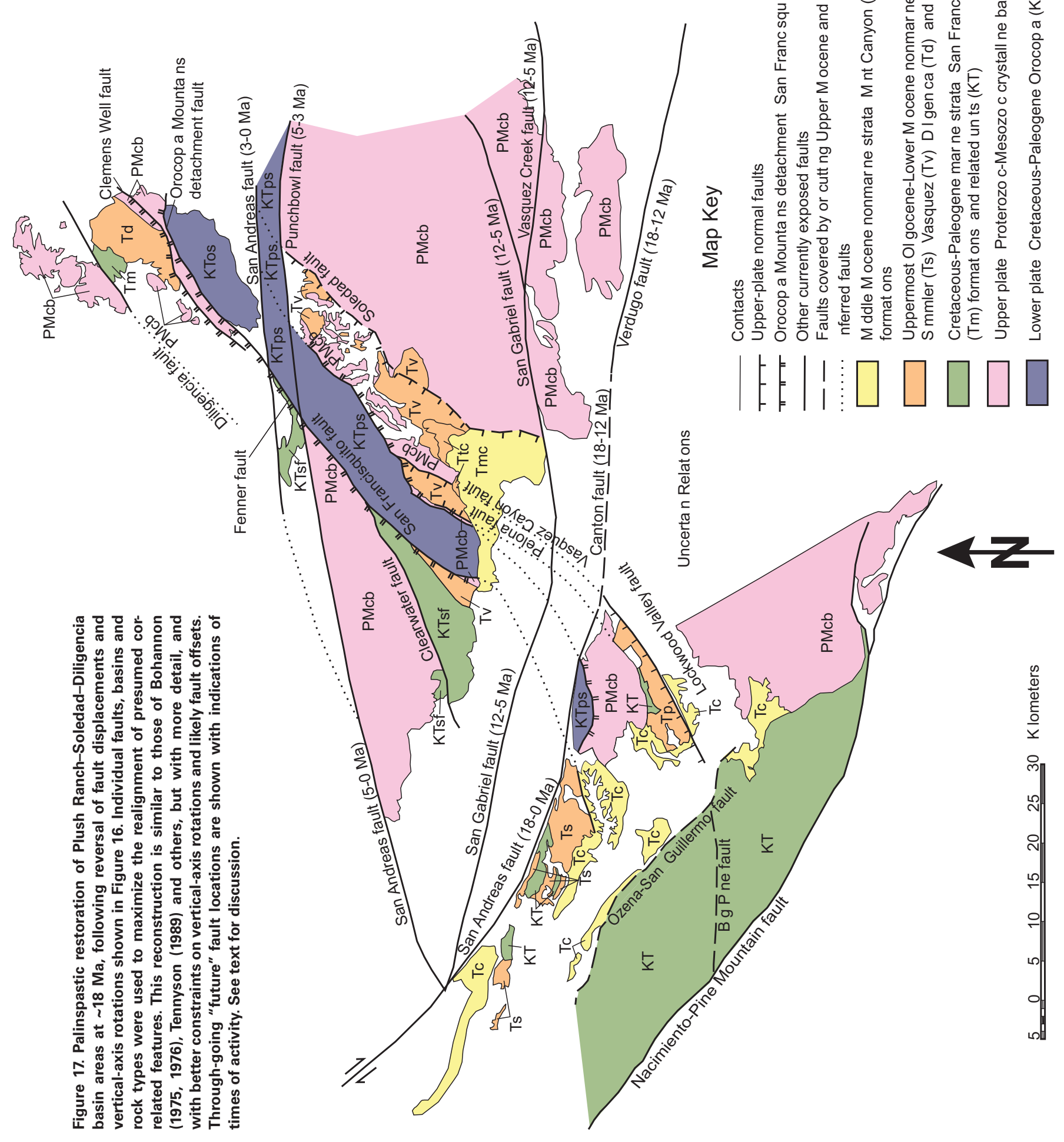




\section{MIOCENE PALEOTECTONICS}

NW-SE-directed extension characterized part of the southwestern California continental margin from around 26-18 Ma (Bohannon, 1975, 1976; Hendrix and Ingersoll, 1987; Tennyson, 1989; Hendrix et al., 2010); this extension preceded and partially coincided with NE-SW extension in the Mojave Desert and Colorado River area (Glazner and Bartley, 1984; Wust, 1986; Sherrod and Tosdal, 1991; Ingersoll et al., 1996; Stewart, 1998; Law et al., 2001). Triple-junction instability (i.e., Ingersoll, 1982) may have been the driving force for NW-SE extension (Hendrix and Ingersoll, 1987; Hendrix et al., 2010). The unstable Mendocino triple junction was located NW of the Simmler-Plush Ranch-Soledad-Diligencia basin complex during this NW-SE extension (Glazner and Loomis, 1984; Hendrix and Ingersoll, 1987; Nicholson et al., 1994; Bohannon and Parsons, 1995; Atwater and Stock, 1998; Hendrix et al., 2010).

During triple-junction-induced NW-SE extension ( 26-20 Ma), the upper crust was thinned and cooled (Jacobson et al., 2007), but the schist was not exposed, as demonstrated by the absence of schist clasts in the Plush Ranch, Vasquez, and Diligencia formations (Bohannon, 1975; Spittler and Arthur, 1982; Hendrix and Ingersoll, 1987; Hendrix, 1993; Hendrix et al., 2010). Surface exposure of the Pelona-Orocopia schists resulted from initiation of transrotation during microplate capture $\sim 18$ Ma (Nicholson et al., 1994; Ingersoll and Rumelhart, 1999; Ingersoll, 2008a, 2008b). The presence of schist clasts in the Middle Miocene Tick Canyon, Mint Canyon and Caliente formations (Fig. 17) (Ehlert, 1982, 2003; Hendrix and Ingersoll, 1987; Ingersoll and Colasanti, 2004; Colasanti and Ingersoll, 2006; Hoyt, 2012) documents additional thinning of the upper crust and exposure of the tectonically underlying Pelona-Orocopia schists beginning $\sim 18 \mathrm{Ma}$. Successive episodes of transrotation ( 18-12 Ma), transtension $(\sim 12-6 \mathrm{Ma})$ and transpression ( 6-0 Ma) in the Los Angeles basin area corresponded with three microplate captures along the southern California continental margin (Nicholson et al., 1994; Bohannon and Parsons, 1995; Ingersoll and Rumelhart, 1999; Ingersoll, 2008a).

\section{CONCLUSIONS}

The Diligencia Formation was deposited in a half graben bounded on the northwest (original orientation) by a SE-dipping high-angle normal fault that was antithetic to a NW-dipping lowangle detachment-fault system between uppercrustal Proterozoic-Mesozoic crystalline rocks and lower-crustal Cretaceous-Paleogene Oro- copia Schist. Late in the history of this basin, the SE-dipping fault ceased movement, and a NWdipping high-angle synthetic fault controlled sedimentation of the upper Diligencia Formation.

The Diligencia basin developed NW of the rising Orocopia antiform, which was not exposed to erosion until after deposition of the Diligenica Formation; upper-plate Proterozoic-Mesozoic crystalline rocks provided most of the detritus. The detachment fault, high-angle faults and basin developed northeast of aligned similar faults in the Soledad and Plush Ranch basin areas, such that the Orocopia and Pelona antiforms were part of the same lower-crustal structure.

Following cessation of rapid NW-SE extension ( 26 to $20 \mathrm{Ma})$ due to instability of the Mendocino triple junction, the following events modified the Early Miocene faults and basins:

1. Microplate capture along the southern California coast induced clockwise transrotation of the western $\left(\sim 90^{\circ}\right)$ and central $\left(\sim 40^{\circ}\right)$ Transverse Ranges blocks (including the Soledad basin), and $\sim 30 \mathrm{~km}$ of dextral slip on the Canton and related faults $(\sim 18-12 \mathrm{Ma})$, which offset the Plush Ranch and Soledad basins.

2. A second microplate capture induced $\sim 40 \mathrm{~km}$ of dextral slip on the San Gabriel and related faults ( 12-6 Ma). This further offset the Plush Ranch and Soledad basins.

3. Complete transfer of Baja California and the Peninsular Ranges to the Pacific plate initiated $240 \mathrm{~km}$ of dextral slip on the southern San Andreas fault, which offset the Soledad and Diligencia basins ( 6-0 Ma). Transrotation of the eastern Transverse Ranges block (including the Diligencia basin; $\sim 90^{\circ}$ ) probably initiated at the same time.

4. N-S shortening of up to $25 \%$ occurred within the Diligencia basin as transrotation ended.

5. Exhumation of the Orocopia Mountains (including the Diligencia basin) has occurred recently due to transpression along the San Andreas fault.

\section{ACKNOWLEDGMENTS}

We gratefully acknowledge gravity and magnetic measurements made by students and staff on joint Caltech-UCLA field trips in 2009 and 2011, using shared geophysical equipment. The Department of Earth, Planetary and Space Sciences, and the Academic Senate of UCLA provided logistical and financial support for this project. We also thank students and teaching assistants from many years of ESS 111 classes for their help and insights.

Detailed reviews by John Goodge, Carl Jacobson, and Sarah Titus greatly improved the manuscript.

\section{REFERENCES CITED}

Advocate, D.M., 1983, Depositional environments of the Eocene Maniobra Formation, northeastern Orocopia Mountains, Riverside County, southern California [M.S. thesis]: California State University, Northridge, 112p.

Advocate, D.M., Link, M.H., and Squires, R.L., 1988, Anatomy and history of an Eocene submarine canyon: the Maniobra Formation, southern California, in Filewicz, M.V., and Squires, R.L., eds., Paleogene stratigraphy, west coast of North America [Book 58]: Pacific Section, Society of Economic Paleontologists and Mineralogists, Los Angeles, p. 45-58.

Armstrong, R.L., and Suppe, J., 1973, Potassium-argon geochronometry of Mesozoic igneous rocks in Nevada, Utah, and southern California: Geological Society of America Bulletin, v. 84, p. 1375-1391, doi:10.1130/0016 -7606(1973)84<1375:PGOMIR>2.0.CO;2.

Arthur, M.A., 1974, Stratigraphy and sedimentation of Lower Miocene nonmarine strata of the Orocopia Mountains: constraints for lateTertiary slip on the San Andreas fault system in southern California [M.S. thesis]: University of California, Riverside, $200 \mathrm{p}$.

Atwater, T., and Stock, J., 1998, Pacific-North America plate tectonics of the Neogene southwestern United States: an update: International Geology Review, v. 40, p. 375402, doi:10.1080/00206819809465216.

Barth, A.P., Wooden, J.L., and Coleman, D.S., 2001, SHRIMPRG U-Pb zircon geochronology of Mesoproterozoic metamorphism and plutonism in the southwesternmost United States: The Journal of Geology, v. 109, p. 319-327, doi:10.1086/319975.

Bartley, J.M., Fletcher, J.M., and Glazner, A.F., 1990, Tertiary extension and contraction of lower-plate rocks in the central Mojave metamorphic core complex, southern California: Tectonics, v. 9, p. 521-534, doi:10.1029 /TC009i003p00521.

Bird, P., 1984, Laramide crustal thickening event in the Rocky Mountain foreland and Great Plains: Tectonics, v. 3, p. 741-758, doi:10.1029/TC003i007p00741.

Bird, P., 1988, Formation of the Rocky Mountains, western United States: a continuum computer model: Science, v. 239 , p. 1501-1507, doi:10.1126/science.239.4847.1501.

Bohannon, R.G., 1975, Mid-Tertiary conglomerates and their bearing on Transverse Range tectonics, southern California, in Crowell, J.C., ed., The San Andreas fault in southern California, a guide to the San Andreas fault from Mexico to the Carrizo Plain: California Division of Mines and Geology Special Report 118, p. 75-82.

Bohannon, R.G., 1976, Mid-Tertiary nonmarine rocks along the San Andreas fault in southern California [Ph.D. thesis]: University of California, Santa Barbara, $311 \mathrm{p}$.

Bohannon, R.G., and Parsons, T., 1995, Tectonic implications of post-30 Ma Pacific and North American relative plate motions: Geological Society of America Bulletin v. 107, p. 937-959, doi:10.1130/0016-7606(1995) 107<0937 :TIOPMP>2.3.CO;2.

Caracciolo, L., Arribas, J., Ingersoll, R.V., and Critelli, S., 2011 The diagenetic destruction of potentially high-quality plutoniclastic reservoirs: the Diligencia and Maniobra formations, Diligencia basin, southern California, USA [poster]: Sediment Provenance Studies in Hydrocarbon Exploration \& Production Conference, 5-7 December 2011, London, Geological Society (London).

Caracciolo, L., Arribus, J., Ingersoll, R.V., and Critelli, S., 2013 , The diagenetic destruction of porosity in plutoniclastic petrofacies: the Miocene Diligencia and Eocene Maniobra formations, Orocopia Mountains, southern California, USA: Geological Society of London Special Publication 386, doi:10.1144/SP386.9 (first published on 15 July 2013).

Carter, J.N., Luyendyk, B.P., and Terres, R.R., 1987, Neogene clockwise tectonic rotation of the eastern Transverse Ranges, California, suggested by paleomagnetic vectors: Geological Society of America Bulletin, v. 98 p. 199-206, doi:10.1130/0016-7606(1987)98<199:NCTROT $>2.0 . \mathrm{CO} ; 2$.

Colasanti, C.V., and Ingersoll, R.V., 2006, Unroofing of the Pelona-Orocopia Schist and palinspastic reconstruction of southern California: Geological Society of America Abstracts with Programs, v. 38, no. 5, p. 19.

Coussot, P., and Meunier, M., 1996, Recognition, classification and mechanical description of debris flows: Earth-Science Reviews, v. 40, p. 209-227, doi:10.1016/0012-8252 (95)00065-8.

Critelli, S., and Le Pera, E., 1994, Detrital modes and provenance of Miocene sandstones and modern sands of the southern Apennines thrust-top basins (Italy): Journal of Sedimentary Research, v. 64, p. 824-835, doi:10.1306 /D4267ED8-2B26-11D7-8648000102C1865D.

Crowell, J.C., 1960, The San Andreas fault in southern California: International Geological Congress Report of the Twenty-First Session Norden, Part 18, p. 45-52. 
Crowell, J.C., 1962, Displacement along the San Andreas fault, California: Geological Society of America Special Paper 71, $61 \mathrm{p}$.

Crowell, J.C., 1973, Problems concerning the San Andreas fault system in southern California, in Kovach, R.L., and Nur, A., eds., Proceedings of the conference on tectonic problems of the San Andreas fault system: Stanford University Publications, Geological Sciences, v. 13, p. 125-135.

Crowell, J.C., 1975a, The San Andreas fault in southern California: California Division of Mines and Geology Special Report 118, p. 7-27.

Crowell, J.C., 1975b, Geologic sketch of the Orocopia Mountains, southeastern California: California Division of Mines and Geology Special Report 118, p. 99-110.

Crowell, J.C., 1981, An outline of the tectonic history of southeastern California, in Ernst, W.G., ed., The geotectonic development of California [Rubey Volume I]: PrenticeHall, Englewood Cliffs, p. 583-600.

Crowell, J.C., 1993, The Diligencia Formation, Orocopia Mountains, southeastern California: U.S. Geological Survey Bulletin, v. 2053, p. 239-242.

Crowell, J.C., 2003, Tectonics of Ridge basin region, southern California, in Crowell, J.C., ed., Evolution of Ridge Basin, Southern California: an interplay of sedimentation and tectonics: Geological Society of America Special Paper 367, p. 157-203, doi:10.1130/0-8137-2367-1.157.

Crowell, J.C., and Susuki, T., 1959, Eocene stratigraphy and paleontology, Orocopia Mountains, southeastern California: Geological Society of America Bulletin, v. 70, p. 581-592, doi:10.1130/0016-7606(1959)70[581:ESAPOM ]2.0.CO;2.

Crowell, J.C., and Walker, J.W.R., 1962, Anorthosite and related rocks along the San Andreas fault southern California: University of California Publications in Geological Sciences, v. 40, p. 219-288.

Davisson, C.M., 1993, Stratigraphic and structural evolution of the early Diligencia basin, Orocopia Mountains, southeastern California [M.S. thesis]: Blacksburg, Virginia Polytechnic Institute and State University, 142p.

Davisson, C.M., Law, R.D., and Eriksson, K.A., 1992, Asymmetric geometry of a half-graben basin as indicated by sediment character; an example from the Diligencia basin, southeastern California: Geological Society of America Abstracts with Programs, v. 24, no. 7, p. A52.

Dibblee, T.W., Jr., 1954, Geology of the Imperial Valley region, California: California Division of Mines Bulletin 170 Chapter 2, p. 21-28, Plate 2.

Dickinson, W.R., 1970, Interpreting detrital modes of graywacke and arkose: Journal of Sedimentary Petrology v. 40, p. $695-707$.

Dickinson, W.R., 1985, Interpreting provenance relations from detrital modes of sandstones, in Zuffa, G.G., ed., Provenance of arenites: Dordrecht, D. Reidel Publishing Co. p. 333-361.

Dickinson, W.R., 1996, Kinematics of transrotational tectonism in the California Transverse Ranges and its contribution to cumulative slip along the San Andreas transform fault system: Geological Society of Americ Special Paper 305, 46 p., doi:10.1130/0-8137-2305-1.1

Dickinson, W.R., and Snyder, W.S., 1978, Plate tectonics of the Laramide orogeny, in Matthews, V., III, ed., Laramide folding associated with basement block faulting in the western United States: Geological Society of America Memoir 151, p. 355-366.

Ebert, K.A., 2004, Exhumation history of the Orocopia Schis and development of hanging-wall structures of the Orocopia fault, southeastern California [M.S. thesis]: University of California, Los Angeles, 124p.

Ehlert, K.W., 1982, Basin analysis of the Miocene Mint Canyon Formation, southern California, in Ingersoll, R.V., and Woodburne, M.O., eds., Cenozoic nonmarine deposits of California and Arizona: Pacific Section, Society of Economic Paleontologists and Mineralogists, Los Angeles, p. 51-64.

Ehlert, K.W., 2003, Tectonic significance of the middle Miocene Mint Canyon and Caliente formations, southern California: Geological Society of America. Special Paper, v. 367, p. 113-130.

Ehlig, P.L., 1958, Geology of the Mount Baldy region of the San Gabriel Mountains, California [Ph.D. thesis]: University of California, Los Angeles, $153 \mathrm{p}$.
Ehlig, P.L., 1968, Causes of distribution of Pelona, Rand, and Orocopia schists along the San Andreas and Garlock faults, in Dickinson, W.R., and Grantz, A., eds., Stanford University Publications Geological Sciences 11, p. 294-305.

Ehlig, P.L., 1981, Origin and tectonic history of the basement terrane of the San Gabriel Mountains, central Transverse Ranges, in Ernst, W.G., ed., The geotectonic development of California [Rubey Volume I]: Prentice-Hall, Englewood Cliffs, p. 253-283.

Frizzell, V.A., Jr., and Weigand, P.W., 1993, Whole-rock K-Ar ages and geochemical data from middle Cenozoic volcanic rocks, southern California: a test of correlations across the San Andreas fault: Geological Society of America, v. 178, p. 273-287, doi:10.1130 MEM178-p273.

Gillies, W.D., 1958, The geology of a portion of Cottonwood Springs quadrangle, Riverside County, California [M.S. thesis]: University of California, Los Angeles, 70p.

Glazner, A.F., and Bartley, J.M., 1984, Timing and tectonic setting ofTertiary low-angle normal faulting and associated magmatism in the southwestern United States:Tectonics, v. 3, p. 385-396, doi:10.1029/TC003i003p00385.

Glazner, A.F., and Loomis, D.P., 1984, Effect of subduction of the Mendocino fracture zone on Tertiary sedimentation in southern California: Sedimentary Geology, v. 38, p. 287-303, doi:10.1016/0037-0738(84)90083-6.

Grove, M., Jacobson, C.E., Barth, A.P., and Vucic, A., 2003, Temporal and spatial trends of Late Cretaceous-early Tertiary underplating of Pelona and related schist beneath southern California and southwestern Arizona, in Johnson, S.E., Paterson, S.R., Fletcher, J.M., Girty, G.H., Kimbrough, D.L., and Martin-Barajas, A., eds., Tectonic evolution of northwestern Mexico and the southwestern U.S.A.: Geological Society of America Special Paper 374, p. 381-406.

Hall, C.A., Jr., 2002, Nearshore marine paleoclimatic regions, increasing zoogeographic provinciality, molluscan extinctions, and paleoshorelines, California: Late Oligocene (27 Ma) to Late Pliocene (2.5 Ma): Geological Society of America Special Paper 357, 489p.

Hall, C.A., Jr., 2007, Introduction to the geology of southern California and its native plants: University of California Press, Berkeley, 493p.

Hendrix, E.D., 1993, Soledad basin, central Transverse Ranges, California, in Sherrod, D.R., and Nielson, J.E., eds., Tertiary stratigraphy of highly extended terranes, California, Arizona and Nevada: U.S. Geological Survey Bulletin 2053, p. 243-251.

Hendrix, E.D., and Ingersoll, R.V., 1987, Tectonics and alluvial sedimentation of the upper Oligocene/lower Miocene Vasquez Formation, Soledad basin, southern California: Geological Society of America Bulletin, v. 98, p. 647663 , doi:10.1130/0016-7606(1987)98<647:TAASOT>2.0 .CO;2.

Hendrix, E.D., Cole, R.B., and Ingersoll, R.V., 2010, Soledad and Plush Ranch basins: mid-Tertiary extensional terrane dismembered by the San Andreas fault system, in Clifton, H.E., and Ingersoll, R.V., eds., Geologic excursions in California and Nevada: tectonics, stratigraphy and hydrogeology: Pacific Section, SEPM (Society for Sedimentary Geology) Book 108, p. 103-171.

Hoyt, J.F., 2012, Provenance and detrital-zircon studies of the Mint Canyon Formation and its correlation to the Caliente Formation, southern California [M.S. thesis]: University of California, Los Angeles, $78 \mathrm{p}$.

Ingersoll, R.V., 1982, Triple-junction instability as cause for late Cenozoic extension and fragmentation of the western United States: Geology, v. 10, p. 621-624 doi:10.1130/0091-7613(1982)10<621:TIACFL>2.0.CO;2.

Ingersoll, R.V., 1997, Phanerozoic tectonic evolution of centra California and environs: International Geology Review, v. 39, p. 957-972, doi:10.1080/00206819709465313.

Ingersoll, R.V., 2008a, Reconstructing southern California, in Spencer, J.E., and Titley, S.R., eds., Circum-Pacific teconics, geologic evolution, and ore deposits: Arizona Geological Society Digest 22, p. 409-417.

Ingersoll, R.V., 2008b, Geological consequences of Miocene initiation of microplate capture and transrotation in southern California, USA: Geological Society of America Abstracts with Programs, v. 40, no. 1, p. 88
Ingersoll, R.V., and Colasanti, C.V., 2004, Unroofing of the Pelona Schist, as documented by sedimentologic evidence along the San Andreas and Punchbowl faults: Programs and Abstracts, 2004 Annual Meeting, Pacific Sections, AAPG, SEPM and SEG, Bakersfield, p. A13-A14.

Ingersoll, R.V., and Rumelhart, P.E., 1999, Three-stage evolution of the Los Angeles basin, southern California: Geology, v. 27, p. 593-596, doi:10.1130/0091-7613(1999)027<0593:TSE OTL>2.3.CO;2 (Correction, v. 27, p. 864).

Ingersoll, R.V., Bullard, T.F., Ford, R.L., Grimm, J.P., Pickle, J.D., and Sares, S.W., 1984, The effect of grain size on detrital modes: a test of the Gazzi-Dickinson pointcounting method: Journal of Sedimentary Petrology, v. 54 , p. $103-116$.

Ingersoll, R.V., Devaney, K.A., Geslin, J.K., Cavazza, W., Diamond, D.S., Heins, W.A., Jagiello, K.J., Marsaglia, K.M. Paylor, E.D., II, and Short, P.F., 1996, The Mud Hills, Mojave Desert, California: structure, stratigraphy, and sedimentology of a rapidly extended terrane: Geological Society of America. Special Paper, v. 303, p. 61-84.

Jacobson, C.E., 1980, Deformation and metamorphism of the Pelona Schist beneath the Vincent thrust, San Gabrie Mountains, California [Ph.D. thesis]: University of California, Los Angeles, 231 p.

Jacobson, C.E., and Dawson, M.R., 1995, Structural and metamorphic evolution of the Orocopia Schist and related rocks, southern California: evidence for late movement on the Orocopia fault:Tectonics, v. 14, p. 933-944, doi:10.1029/95TC01446.

Jacobson, C.E., Dawson, M.R., and Postlethwaite, C.E., 1988 Structure, metamorphism, and tectonic significance of the Pelona, Orocopia, and Rand Schists, southern California, in Ernst, W.G., ed., Metamorphism and crustal evolution of the western United States [Rubey Volume VII]: Prentice-Hall, Englewood Cliffs, p. 976-997.

Jacobson, C.E Oyarzabal, FR and Haxel, G.B. 1996, Subduction and exhumation of the Pelona-Orocopia-Rand schists, southern California: Geology, v. 24, p. 547-550, doi:10.1130/0091-7613(1996)024<0547:SAEOTP>2.3 .CO;2.

Jacobson, C.E., Barth, A.P., and Grove, M., 2000, Late Cretaceous protolith age and provenance of the Pelona and Orocopia Schists, southern California: implications for evolution of the Cordilleran margin: Geology, v. 28 p. 219-222, doi:10.1130/0091-7613(2000)28<219:LCPAAP $>2.0 . \mathrm{CO} ; 2$.

Jacobson, C.E., Grove, M., Stamp, M.M., Vucic, A., Oyarzabal, FR., Haxel, G.B., Tosdal, R.M., and Sherrod, D.R., 2002, Exhumation of the Orocopia Schist and related rocks in the Gavilan Hills area of southeasternmost California, in Barth, A., ed., Contributions to Crustal Evolution of the Southwestern United States: Geological Society of America Special Paper 365, p. 129-154, doi:10.1130/0 -8137-2365-5.129.

Jacobson, C.E., Grove, M., Vucic, A., Pedrick, J.N., and Ebert, K.A., 2007, Exhumation of the Orocopia Schist and associated rocks of southeastern California: Relative rates of erosion, synsubduction tectonic denudation, and middle Cenozoic extension, in Cloos, M., et al., eds. Convergent Margin Terranes and Associated Regions: A Tribute to W.G. Ernst: Geological Society of America Special Paper 419, p. 1-37.

Jacobson, C.E., Grove, M., Pedrick, J.N., Barth, A.P., Marsaglia K.M., Gehrels, G.E., and Nourse, J.A., 2011, Late Cretaceous-early Cenozoic tectonic evolution of the southern California margin inferred from provenance of trench and forearc sediments: Geological Society of America Bulletin, v. 123, p. 485-506, doi:10.1130/B30238.1.

Johnston, I.M., 1961, Eocene foraminifera from the lowe Maniobra Formation, Orocopia Mountains, Riverside County, California [M.A. thesis]: University of California, Berkeley, $93 \mathrm{p}$

Joseph, S.E., Davis, T.E., and Ehlig, P.L., 1982, Strontium isotopic correlation of the La Panza Range granitic rock with similar rocks in the central and eastern Transverse Ranges, in Fife, D.L., and Minch, J.A., eds., Geology and mineral wealth of the California Transverse Ranges: South Coast Geological Society, Santa Ana, p. 310-320.

Kirkpatrick, J.C., 1958, A study of some marine Middle Eocene formations in southern California [M.S. thesis] University of California, Los Angeles, 75 p. 
Kooser, M., 1982, Stratigraphy and sedimentology of the type San Francisquito Formation, southern California, in Crowell, J.C., and Link, M.H., eds., Geologic history of Ridge basin, southern California: Pacific Section, Society of Economic Paleontologists and Mineralogists, Los Angeles, p. 53-61.

Law, R.D., Eriksson, K., and Davisson, C., 2001, Formation, evolution, and inversion of the middle Tertiary Diligencia basin, Orocopia Mountains, southern California: Geological Society of America Bulletin, v. 113, p. 196221, doi:10.1130/0016-7606(2001)113<0196:FEAIOT $>2.0 . \mathrm{CO} ; 2$.

Livaccari, R.F., Burke, K., and Şengör, A.M.C., 1981, Was the Laramide orogeny related to subduction of an oceanic plateau?: Nature, v. 289 , p. $276-278$, doi:10.1038 /289276a0

Luyendyk, B.P., 1991, A model for Neogene crustal rotations, transtension, and transpression in southern California: Geological Society of America Bulletin, v. 103, p. 1528 1536, doi:10.1130/0016-7606(1991)103<1528:AMFNCR>2 .3.CO;2.

Matti, J.C., and Morton, D.M., 1993, Paleogeographic evolution of the San Andreas fault in southern California: reconstruction based on a new cross-fault correlation, in Powell, R.E., et al., eds., The San Andreas Fault System: Displacement, Palinspastic Reconstruction, and Geologic Evolution: Geological Society of America Memoir 178, p. 107-159.

Miller, W.J., 1944, Geology of Palm Springs-Blythe strip, Riverside County, California: California Journal of Mines and Geology, v. 40, p. 11-72.

Morton, D.M., and Matti, J.C., 1993, Extension and contraction within an evolving divergent strike-slip fault complex: the San Andreas and San Jacinto fault zones at their convergence in southern California, in Powell, R.E., et al., eds., The San Andreas Fault System: Displacement, Palinspastic Reconstruction, and Geologic Evolution: Geological Society of America Memoir 178, p. 217-230.

Nicholson, C., Sorlien, C.C., Atwater, T., Crowell, J.C., and Luyendyk, B.P., 1994, Microplate capture, rotation of the western Transverse Ranges, and initiation of the San Andreas transform as a low-angle fault system: Geology, v. 22, p. 491-495, doi:10.1130/0091-7613(1994)022<0491 :MCROTW>2.3.CO;2.

Onderdonk, N.W., 2005, Structures that accommodated differential vertical axis rotation of the western Transverse Ranges, California: Tectonics, v. 24, TC4018, p. 15 p doi:10.1029/2004TC001769.

Oskin, M., and Stock, J., 2003, Marine incursion synchronous with plate-boundary localization in the Gulf of California: Geology, v. 31, p. 23-26, doi:10.1130/0091 7613(2003)031<0023:MISWPB>2.0.CO;2.

Oskin, M., Stock, J., and Martin-Barajas, A., 2001, Rapid localization of Pacific-North America plate motion in the Gulf of California: Geology, v. 29, p. 459-462, doi:10.1130/0091 -7613(2001)029<0459:RLOPNA>2.0.CO;2.

Potter, P.E., and Pettijohn, F.J., 1977, Paleocurrents and basin analysis (Second, corrected and updated edition): Springer-Verlag, New York, p. 312-363.

Powell, R.E., 1981, Geology of the crystalline basement complex, eastern Transverse Ranges, southern California: constraints on regional tectonic interpretations [Ph.D. thesis]: California Institute of Technology, Pasadena, $441 \mathrm{p}$.

Powell, R.E., 1993, Balanced palinspastic reconstruction of pre-late Cenozoic paleogeology, southern California: geologic and kinematic constraints on evolution of the San Andreas fault system, in Powell, R.E., et al., eds., The San Andreas Fault System: Displacement, Palinspastic Reconstruction, and Geologic Evolution:
Geological Society of America Memoir 178, p. 1-106, doi:10.1130/MEM178-p1.

Powell, R.E., and Weldon, R.J., II, 1992, Evolution of the San Andreas fault: Annual Review of Earth and Planetary Sciences, v. 20, p. 431-468, doi:10.1146/annurev .ea.20.050192.002243.

Prothero, D.R., and Dott, R.H., 2002, Evolution of the Earth [6th Edition]: McGraw-Hill, NewYork, 569 p.

Richard, S.M., 1993, Palinspastic reconstruction of southeastern California and southwestern Arizona for the Middle Miocene:Tectonics, v. 12, p. 830-854, doi:10.1029 /92TC02951.

Robinson, K.L., and Frost, E.G., 1996, Orocopia Mountains detachment system: progressive development of a tilted crustal slab and half-graben sedimentary basin during regional extension, in Abbott, P.L., and Cooper, J.D., eds., Field Conference Guide1996: Pacific Section, American Association of Petroleum Geologists, Bakersfield, p. 277-284.

Saleeby, J., 2003, Segmentation of the Laramide slab-Evidence from the southern Sierra Nevada region: Geological Society of America Bulletin, v. 115, p. 655-668, doi:10.1130/0016-7606(2003)115<0655:SOTLSF>2.0 CO;2.

Sherrod, D.R., and Tosdal, R.M., 1991, Geologic setting and Tertiary structural evolution of southwestern Arizona and southeastern California: Journal of Geophysical Research, v. 96, p. 12,407-12,423, doi:10.1029/90JB02688.

Silver, L.T., 1971, Problems of crystalline rocks of the Transverse Ranges: Geological Society of America Abstracts with Programs, v. 3, p. 193-194.

Silver, L.T., McKinney, C.R., Deutsch, S., and Bolinger, J., 1963, Precambrian age determinations in the western San Gabriel Mountains, California:The Journal of Geology, v. 71, p. 196-214, doi:10.1086/626893.

Smith, D.P., 1977, San Juan-St. Francis fault: hypothesized major middle Tertiary right-lateral fault in central and southern California: California Division of Mines and Geology Special Report 129, p. 41-50.

Smith, G.A., and Lowe, D.R., 1991, Lahars: volcano-hydrologic events and deposition in the debris flow-hyperconcentrated flow continuum: SEPM (Society for Sedimentary Geology) Special Publication 45, p. 59-70.

Spittler, T.E., 1974, Volcanic petrology and stratigraphy of nonmarine strata, Orocopia Mountains: their bearing on Neogene slip on the San Andrea fault, southern California [M.S. thesis]: University of California, Riverside, $115 \mathrm{p}$.

Spittler, T.E., and Arthur, M.A., 1973, Post Early Miocene displacement along the San Andreas fault in southern California, in Kovach, R.L., and Nur, A., eds., Proceedings of the conference on tectonic problems of the San Andreas fault system: Stanford University Publications, Geological Sciences, v. 13, p. 374-382.

Spittler, T.E., and Arthur, M.A., 1982, The Lower Miocene Diligencia Formation of the Orocopia Mts., southern California: stratigraphy, petrology, sedimentology and structure, in Ingersoll, R.V., and Woodburne, M.O., eds. Cenozoic nonmarine deposits of California and Arizona: Pacific Section, Society of Economic Paleontologists and Mineralogists, Los Angeles, p. 83-99.

Squires, R.L., and Advocate, D.M., 1982, Sedimentary facies of the nonmarine Lower Miocene Diligencia Formation, Canyon Spring area, Orocopia Mountains, southern California, in Ingersoll, R.V., and Woodburne, M.O., eds. Cenozoic nonmarine deposits of California and Arizona: Pacific Section, Society of Economic Paleontologists and Mineralogists, Los Angeles, p. 101-106.

Squires, R.L., and Advocate, D.M., 1986, New early Eocene mollusks from the Orocopia Mountains, southern California: Journal of Paleontology, v. 60, p. 851-864.
Stewart, J.H., 1998, Regional characteristics, tilt domains, and extensional history of the late Cenozoic Basin and Range province, western North America, in Faulds, J.E. and Stewart, J.H., eds., Accommodation zones and transfer zones: the regional segmentation of the Basin and Range province: Geological Society of America Special Paper 323, p. 47-74.

Talwani, M., Worzel, J.L., and Landisman, M., 1959, Rapid gravity computations for two-dimensional bodies with application to the Mendocino Submarine Fracture Zone: Journal of Geophysical Research, v. 64, p. 49-59, doi:10.1029/JZ064i001p00049.

Telford, W.M., Geldart, L.P., and Sheriff, R.E., 1998, Applied geophysics: Cambridge University Press, Cambridge, $770 \mathrm{p}$

Tennyson, M.E., 1989, Pre-transform early Miocene extension in western California: Geology, v. 17, p. 792-796, doi:10.1130/0091-7613(1989)017<0792:PTEMEI>2.3.CO;2.

Terres, R.R., 1984, Paleomagnetism and tectonics of the central and eastern Transverse Ranges, southern California [Ph.D. thesis]: University of California, Santa Barbara, $325 \mathrm{p}$.

Terres, R.R., and Luyendyk, B.P., 1985, Neogene tectonic rotation of the San Gabriel region, California, sug gested by paleomagnetic vectors: Journal of Geophysical Research, v. 90, p. 12,467-12,484, doi:10.1029/ JB090iB14p12467.

Weldon, R.J., II, Meisling, K.E., and Alexander, J., 1993, A speculative history of the San Andreas fault in the central Transverse Ranges, California in Powell, R.E., et al., eds., The San Andreas Fault System: Displacement, Palinspastic Reconstruction, and Geologic Evolution: Geological Society of America Memoir 178, p. 161-198.

Williams, H.,Turner, F.J., and Gilbert, C.M., 1954, Petrography: an introduction to the study of rocks in thin sections: San Francisco, W.H. Freeman and Company, 406 p.

Williams, J.J., 1956, Geology of part of the Orocopia Mountains, Riverside County, California [M.A. thesis]: University of California, Los Angeles, $43 \mathrm{p}$.

Woodburne, M.O., and Whistler, D.P., 1973, An Early Miocene oreodont (Merychyinae, Mammalia) from the Orocopia Mountains, southern California: Journal of Paleontology, v. 47, p. 908-912.

Wust, S.L., 1986, Regional correlation of extension directions in Cordilleran metamorphic core complexes: Geology, v. 14 , p. $828-830$, doi:10.1130/0091-7613(1986)14<828 :RCOEDI>2.0.CO;2.

Yarnold, J.C., 1993, Rock-avalanche characteristics in dry climates and the effect of flow into lakes: insights from mid-Tertiary sedimentary breccias near Artillery Peak Arizona: Geological Society of America Bulletin, v. 105 p.345-360, doi:10.1130/0016-7606(1993)105<0345:RACIDC $>2.3 . \mathrm{CO} ; 2$.

Yarnold, J.C., and Lombard, J.P., 1989, A facies model for large rock-avalanche deposits formed in dry climates, in Colburn, I.P., Abbott, P.L., and Minch, J., eds., Conglomerates in basin analysis: a symposium dedicated to A.O. Woodford: Society of Economic Paleontologists and Mineralogists, Pacific Section, Los Angeles, p. 9-31.

Zuffa, G.G., 1985, Optical analyses of arenites: influence of methodology on compositional results, in Zuffa, G.G. ed., Provenance of arenites: Dordrecht, D. Reidel Publishing Co., p. 165-189.

Zuffa, G.G., 1987, Unravelling hinterland and offshore palaeogeography from deep-water arenites, in Leggett, J.K. and Zuffa, G.G., eds., Marine clastic sedimentology: London, Graham andTrotman, p. 39-61. 